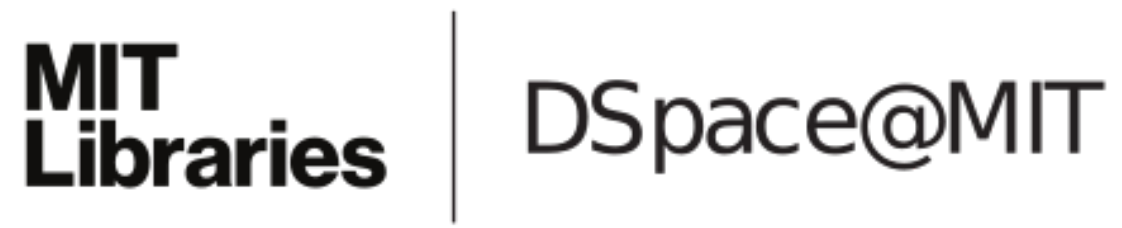

\author{
MIT Open Access Articles
}

Fodder, pasture, and the development of complex society in the Chalcolithic: isotopic perspectives on animal husbandry at Marj Rabba

The MIT Faculty has made this article openly available. Please share how this access benefits you. Your story matters.

Citation: Price, Max et al. "Fodder, pasture, and the development of complex society in the Chalcolithic: isotopic perspectives on animal husbandry." Archaeological and Anthropological Sciences 12, 4 (March 2020): 95 (C) 2020 Springer-Verlag

As Published: http://dx.doi.org/10.1007/s12520-020-01043-z

Publisher: Springer Science and Business Media LLC

Persistent URL: https://hdl.handle.net/1721.1/128382

Version: Author's final manuscript: final author's manuscript post peer review, without publisher's formatting or copy editing

Terms of Use: Article is made available in accordance with the publisher's policy and may be subject to US copyright law. Please refer to the publisher's site for terms of use. 


\section{Fodder, Pasture, and the Development of Complex Society in the Chalcolithic: Isotopic Perspectives on Animal Husbandry at Marj Rabba}

Cite this article as: Max Price, Yorke M. Rowan, Morag M. Kersel, Cheryl A. Makarewicz, Fodder, Pasture, and the Development of Complex Society in the Chalcolithic: Isotopic Perspectives on Animal Husbandry at Marj Rabba, Archaeological and Anthropological Sciences, doi: 10.1007/s12520-020-01043-z

This Author Accepted Manuscript is a PDF file of a an unedited peer-reviewed manuscript that has been accepted for publication but has not been copyedited or corrected. The official version of record that is published in the journal is kept up to date and so may therefore differ from this version.

Terms of use and reuse: academic research for non-commercial purposes, see here for full terms. http://www.springer.com/gb/open-access/authors-rights/aam$\underline{\text { terms-v1 }}$ 
Title: Fodder, Pasture, and the Development of Complex Society in the Chalcolithic: Isotopic Perspectives on Animal Husbandry at Marj Rabba

\title{
Authors
}

Max Price ${ }^{1,4}$

Yorke M. Rowan ${ }^{2}$

Morag M. Kersel ${ }^{3}$

Cheryl A. Makarewicz ${ }^{4}$

1 - Department of Materials Science and Engineering, MIT, 77 Massachusetts Avenue, Cambridge, MA 02139, USA

2 - Oriental Institute, University of Chicago, 1177 E $58^{\text {th }}$ Street, Chicago, IL 60637, USA

3- Department of Anthropology, DePaul University, 2347 N. Racine, Chicago, IL 60614, USA

4 - Institute for Prehistoric and Protohistoric Archaeology, Kiel University, JohannaMestorf Strasse 2-6, Germany, D-24118

\begin{abstract}
The emergence of social complexity in the southern Levant during the Chalcolithic (c. 4500 - 3600 cal. BC) was intimately tied to intensification in animal management. For the first time, secondary products such as milk and wool were intensively exploited, supplying communities with increasingly diverse foodstuffs and raw materials for craft production and exchange, but the precise herding practices underlying these new production strategies are unknown. Here, we explore the role of
\end{abstract}


multi-species livestock pasturing through carbon and nitrogen isotopic analysis of animal bones from Marj Rabba in the Lower Galilee (ca. 4600-4200 cal. BC). Isotopic results suggest different pasturing/foddering of sheep compared to goats. Cattle were largely pastured locally, but high $\delta^{13} \mathrm{C}$ values in some animals indicate access to the Jordan River Valley (the Ghor in Arabic), where major Chalcolithic settlements were situated. This may indicate some cattle were moved along regional Chalcolithic exchange networks established for other prestige objects, such as copper. Finally, we provide evidence for moderate ${ }^{15} \mathrm{~N}$ enrichment in pigs relative to herbivorous livestock indicates. Possible interpretations include consumption of nuts (esp. acorns), household refuse containing animal protein, and/or fattening pigs on grain. Although an interpretation that requires further exploration, grain-foddering of pigs would complement the zooarchaeological data for early slaughter, which suggests intensive meat production at Marj Rabba. It might also help explain why pig husbandry, as a drain on grain stockpiles, was gradually abandoned during the Bronze Age. Taken together, the isotopic and zooarchaeological data indicate an economy in transition from a non-specialized, household-based Neolithic economy to one in which the production of agrarian wealth, including animal secondary products, was beginning to emerge.

Keywords: Zooarchaeology, Stable isotopes, Carbon, Nitrogen, Chalcolithic, Levant

\section{Acknowledgments}

We wish to thank the Oriental Institute of the University of Chicago for its support of the Galilee Prehistory Project and the excavations at Marj Rabba. Thanks also 
to Andrea Dudek, Phil Graham, Austin (Chad) Hill, Michael Homan, Brittany Jackson, and Dina Shalem - senior members of the Marj Rabba excavations. Over six seasons, the bones were carefully recovered by student excavators; we are grateful for their dedication to the project. We also wish to extend our gratitude to the Israel Antiquities Authority for permission to excavate and export animal bones from Marj Rabba. We thank Bob Michener (Boston University) for assistance with mass spectrometry, as well as Richard Meadow (Zooarchaeology Lab) and Robert Ackert (Archaeology Multi-User Lab) at Harvard University. Karin Winter helped with graphics. Funding for the isotopic analysis was provided by the Alexander von Humboldt-Stiftung and the Archaeological Stable Isotope Laboratory (Kiel University). 


\section{Introduction}

The Chalcolithic (c. 4500-3600 cal. BC) in the southern Levant was a critical moment in the evolution of complex societies. Population expansion, increased visibility of ritual architecture, greater social investment in ritual practice, and craft specialization all took place at this time (Rowan \& Golden 2009). These changes coincided with - and were likely connected to - transformations in livestock management that sought to regularly exploit "secondary products" including milk, fiber, and traction power. Pigs, animals that generate no secondary products, provided a major source of meat and fat to Chalcolithic communities across the region (Grigson 1998; Price et al. 2013). Landscape use also appears to have shifted during the Chalcolithic. Abundant chipped stone axes recovered from Chalcolithic sites (Rowan \& Golden 2009: 28) and a marked rise in the frequency of Olea pollen in lake cores (Litt et al. 2012; Schiebel 2013) suggest land clearance for agriculture and arboriculture. Additionally, small, ephemeral sites were established outside of the core settlement zones of the Jordan River Valley (colloquially referred to as the Ghor, the Arabic word for "valley") and the northern Negev. This shift in settlement patterns, suggestive of mobile herding (Epstein 1978; Levy 1983, 1992; Bourke 2001), may reflect intensification in animal production and its coordination with intensive cereal agriculture. However, it remains to be seen how, if at all, animals were distributed across the landscape and what strategies livestock keepers employed to feed their herds.

Here, we explore Chalcolithic landscape use, in the form of livestock pasturing, through analysis of carbon and nitrogen isotopes from animal remains recovered from Marj Rabba. Carbon and nitrogen isotopes of collagenous tissues reflect animal dietary 
intake, offering insight into habitat vegetation dynamics, mobility, habitat exploitation, and changes in foddering regimes (Makarewicz \& Tuross 2012; Hamilton et al. 2009; Pickard et al. 2017). Marj Rabba is a roughly eight-hectare site located in the hilly Lower Galilee (Figure 1). The relatively well-watered landscapes of the Lower and, especially, Upper Galilee provided ideal pasturelands as well as opportunities for growing grains and fruits. To the south and east, the fertile Jordan Valley also supported large communities of agropastoralists. Marj Rabba's location, size, and robust faunal assemblage make it an ideal site to test questions related to landscape use and animal management in the Chalcolithic.

\section{Animals and Socioeconomic Change in the Chalcolithic}

The Chalcolithic period witnessed profound shifts in demography, economic organization, and ritual activities that, altogether, contributed to new forms of sociopolitical organization. After an extended period of settlement retraction during the Pottery Neolithic, large settlements of up to 10 hectares sprang up across the southern Levant, particularly in the Jordan River Valley and to its west (Finkelstein \& Gophna 1993; Gibson \& Rowan 2006; Shalem 2008). People settled in previously sparsely inhabited regions, such as the Negev and Golan (Epstein 1978; Levy 1992). At the same time, craft production became more specialized. Wheel-made pottery appeared for the first time (Kerner 2010) and concentrations of weaving tools at some sites (e.g., Gilat) suggest specialization of textile production (Levy et al. 2006). Metal production was also specialized. At the Chalcolithic-EB I sites of Tell Hujayrat al-Ghuzlan and Tell alMagass in the Aqaba region, craftsman smelted and cast copper in considerable quantities 
(Notroff et al. 2014). In a similar fashion, evidence for metalworking at northern Negev sites such as Shiqmim and Abu Matar included crucibles, slags, and ores yielding chemical compositions indicating Faynan ore sources (Golden et al. 2001).

Diversification and elaboration of ritual activity were likely tied to these demographic and economic changes. The archaeological record of the Chalcolithic is replete with an abundance of ritual material culture, such as miniature vessels, female figurines, and elaborate wall decorations depicting animals and people (Joffe et al. 2001; Lovell 2010; Drabsch 2015). Burial traditions diversified to include both primary and secondary burials, the latter of which were often interred in stylized ceramic ossuaries (Rowan \& Golden 2009; Shalem et al. 2013; Ilan \& Rowan 2019). People congregated at what some have argued were "cultic" centers or at sites with "temples." Notable examples are Gilat, Tulaylat Ghassul (sometimes spelled "Teleilat al-Ghassul”), and Ein Gedi (Rowan \& Golden 2009).

Debate persists over whether these ritual and economic changes represent a society that had developed a hierarchical ("chiefdom") level of organization (Gopher \& Tsuk 1996; Levy 1998), or whether Chalcolithic communities were egalitarian (Joffe et al. 2001). While direct evidence for elites and hierarchical organization is limited, some have suggested that elaborate rituals, perhaps coordinated by specialist religious practitioners (Levy 2006; Rowan \& Ilan 2007; Ilan \& Rowan 2012), served as an impetus towards greater economic specialization and coordination among increasing large and dispersed populations. Chalcolithic sites are also notable, especially in comparison to previous periods, for the presence of prestige goods, such as maceheads, palettes, and other objects made of ivory, copper, and polished stone (Rowan and Golden 2009: 9). 
Again, it remains unclear if these objects functioned in ritual contexts defined by achieved status or whether emerging hereditary elites were attempting to accumulate prestige goods on their paths to political power.

Whatever their specific forms of sociopolitical organization, Chalcolithic societies were founded upon an agropastoral base that facilitated social elaboration. Accumulated foodstuffs fueled a more specialized economy, enabled feasts, and potentially may have been a source of elite economic power. Indeed, archaeobotanical and zooarchaeological data indicate substantial subsistence developments during the Chalcolithic. Pollen cores from the Dead Sea and macrobotanical evidence from Chalcolithic sites in the Jordan River Valley and the Galilee/Golan indicate extensive olive production beginning in the mid- $5^{\text {th }}$ millennium cal. BC (Epstein 1978; Bourke 2001; Litt et al. 2012; Graham 2018). Cereal cultivation also expanded, signaled by the high relative abundances of wheat and barley in archaeobotanical assemblages, the proliferation of sickle blades, and the high rates of caries and other dental pathologies in Chalcolithic skeletons (Smith et al. 2003; Rowan \& Golden 2009; Graham 2018). Similarly, large-scale storage facilities at, for example, Tulaylat Ghassul might indicate control over distribution (Bourke 2001: 117).

In terms of animal production, the Chalcolithic has long been thought to herald the so-called "secondary products revolution" (Sherratt 1983; Grigson 1998). This is a somewhat hyperbolic term for the intensification of the exploitation of animals for nonmeat products such as milk, traction, and animal fiber. It is important to recognize that, in contrast to Andrew Sherratt's (1983) original hypothesis, the Chalcolithic was not the first time that secondary products were exploited (Vigne \& Helmer 2007; Evershed et al. 2008). Rather, the Chalcolithic represents a period in which herders began to adjust their 
management strategies to target and eventually maximize the production of milk, animal hair, and traction.

Several lines of evidence indicate the intensification of secondary product exploitation. Some faunal assemblages, such as Gilat (Grigson 2006) and Tulaylat Ghassul (Bourke et al. 2007), show increased survivorship of adult sheep/goat, a harvesting profile consistent with theoretical models that emphasize long-term herd security or meat production is visible at some sites. Evidence for milk and hair production also includes the proliferation of ceramic churns, spindle whorls, and an abundance of weaving implements made from animal bones (e.g., at Gilat: Commenge et al. 2006; Levy et al. 2006). There is also occasional evidence for traction pathologies on the distal limbs of cattle at some sites, indicating the use of these animals for plowing (Grigson 1995; Hill 2011; Price et al. 2013).

The abundance of pigs at Chalcolithic sites, on the other hand, indicates that secondary products were far from being the sole focus of Chalcolithic animal husbandry. The remains of pigs, animals that do not provide hair for textiles or abundant milk for dairy production, regularly exceed $25 \%$ of the fauna (by Number of Identified Specimens - NISP) in the Galilee, Coastal, and Jordan River Valley regions (Grigson 1995, 1998; Price et al. 2013). This pattern is consistent with animal exploitation at preceding Late Neolithic sites in the region (Horwitz 2002: 168; Marom \& Bar-Oz 2013), but differs significantly from the low proportions of pigs found at sites dating to the Early Bronze Age and later. Beginning in the Early Bronze Age (3600-2000 cal. BC), the importance of pigs gradually declined, becoming an insignificant part of the typical Levantine diet by the second millennium BC (Allentuck 2013: 164-169). While some authors have 
attributed this decline to climate change, specifically increased aridity (Allentuck and Rosen 2019), the retention of cattle in the Bronze Age and the addition/expansion of crops requiring significant amounts of water in the Early Bronze Age (e.g., grapes and flax; see Reihl 2008) strongly suggest that water scarcity was not the main reason for the decline of pig husbandry. Moreover, pig husbandry primarily declined during the EB IIIII, a period characterized by relatively more rainfall than the preceding EB I (BarMatthews \& Ayalon 2011). The demise of pig husbandry should be understood not so much in terms of climate change (though we do not deny that this may have played an important role in some contexts), but rather in the specific ways that people raised these animals in relation to other human-environmental interactions and economic activities. In that vein, we ask whether Chalcolithic pig husbandry practices might shed light on pork's gradual disappearance from the Levantine diet.

Semi-specialized or mobile pastoralism may have formed an important component of the Chalcolithic economy. Survey data from the Negev indicates the presence of ephemeral sites located outside the Nahal Besor floodplain, where major settlements and, presumably, cereal agriculture were concentrated (Levy 1983). However, the transient sites were located in proximity to ideal summer and winter pastures for ruminants. This might therefore reflect a more mobile system of pastoralism of sheep and goats designed to avoid competition between herding and grain production or to take advantage of seasonally-available pastures (Levy 1983). Others have contended that, since animals in all age classes were present in the bone assemblages of major settlements in the region, herding was localized and non-mobile (Grigson 1998). 


\section{Animal Management at Marj Rabba}

Marj Rabba $\left(32.844^{\circ} \mathrm{N}, 35.282^{\circ} \mathrm{E}, \mathrm{c} .450\right.$ masl) is one of about three dozen known Chalcolithic sites in the Galilee (Shalem 2008). The areal extent of the sherd scatter (c. 8 ha) and dense palimpsest of stone architecture revealed by ground-penetrating radar (Urban et al. 2014) indicates a sizable village, with four phases radiocarbon dated to 4600-4200 cal. BC. Excavations were carried out between 2009 and 2014 (Rowan \& Kersel 2014; Urban et al. 2014). In addition to domestic architecture, the excavators uncovered two seemingly ritual features: a pit containing the articulated remains of two cattle (Hill et al. 2016) and a uniquely- and well-constructed building (Building 1) containing the remains of several gazelle feet as well as a human foot (Price et al. 2016).

Archaeobotanical and faunal data from Marj Rabba indicate a mixed agricultural economy. Among the plant remains, wheat and barley predominated, followed by lentils, olives, and peas (Graham 2018). The animal remains (Table 1) show a predominance of domestic livestock. Gazelle were also present, although the majority of these remains (N =256) derive from the previously mentioned Building 1 and probably reflect ritual, not quotidian, activities.

Table 1. Main animal taxa from the Marj Rabba faunal assemblage. "Sheep/Goat" includes specimens identified specifically as "sheep" or "goat" in the subsequent lines.

\begin{tabular}{|l|l|l|}
\hline Taxon & NISP & $\%$ NISP \\
\hline Cattle (Bos taurus) & 750 & $13 \%$ \\
\hline Sheep/Goat & 2855 & $50 \%$ \\
\hline Sheep (Ovis aries) & $(182)$ & \\
\hline Goat (Capra hircus) & $(239)$ & \\
\hline Pig (Sus scrofa) & 1685 & $30 \%$ \\
\hline Gazelle (Gazella gazella) & 373 & $7 \%$ \\
\hline
\end{tabular}


Ongoing research at Marj Rabba has examined secondary products exploitation. Collagen peptide fingerprinting (ZooMS) assigned 52 mandibles bearing age at death information to genus (Capra or Ovis), allowing computation of sheep and goat survivorship separately (Price et al. 2013). The demographic profiles between the two species were not significantly different (Kolmogorov-Smirnov test: $\mathrm{D}=.333, \mathrm{P}=.699$ ) and both demographic profiles were broadly comparable to risk-minimizing (or meatfocused) production models (Payne 1972; Redding 1981). On the other hand, sheep were slaughtered somewhat later than goats, with $25 \%$ of animals surviving past four years of age (Payne's age classes G-I) compared to $13 \%$ for goats (Table 2). In fact, this pattern of slightly older kill-off for sheep has been found repeatedly at Chalcolithic sites, including Bir es-Safadi (Grigson 1987) and Gilat (Grigson 2006) in the northern Negev as well as early $5^{\text {th }}$ millennium Tel Tsaf (Hill 2011). This could be taken as evidence for a slight (or emerging) emphasis on wool exploitation.

Table 2. Sheep/goat suggested ages for Payne's age classes, published by Payne (1973: 293). *Ages in months.

\begin{tabular}{|l|r|r|r|r|r|r|r|}
\hline $\begin{array}{l}\text { Age } \\
\text { Class }\end{array}$ & $\begin{array}{r}\text { MNE } \\
\text { Sheep/Goat }\end{array}$ & $\begin{array}{r}\text { Sheep/Goat } \\
\text { \% Surviving }\end{array}$ & $\begin{array}{r}\text { MNE } \\
\text { Sheep }\end{array}$ & $\begin{array}{r}\text { Sheep } \\
\text { \% Surviving }\end{array}$ & $\begin{array}{r}\text { MNE } \\
\text { Goat }\end{array}$ & $\begin{array}{r}\text { Goat } \\
\text { Surviving }\end{array}$ & $\begin{array}{r}\text { Est. } \\
\text { Age* }\end{array}$ \\
\hline A & 1 & 99 & 0 & 100 & 0 & 100 & $0-2$ \\
\hline $\mathrm{B}$ & 1 & 98 & 1 & 95 & 0 & 100 & $2-6$ \\
\hline $\mathrm{C}$ & 23 & 73 & 5 & 70 & 8 & 75 & $6-12$ \\
\hline $\mathrm{D}$ & 16 & 55 & 3 & 55 & 8 & 50 & $12-24$ \\
\hline $\mathrm{E}$ & 12 & 42 & 2 & 45 & 4 & 38 & $24-36$ \\
\hline $\mathrm{F}$ & 15 & 25 & 2 & 35 & 8 & 13 & $36-48$ \\
\hline $\mathrm{G}$ & 12 & 12 & 4 & 15 & 2 & 6 & $48-72$ \\
\hline $\mathrm{H}$ & 5 & 7 & 2 & 5 & 2 & 0 & $72-96$ \\
\hline $\mathrm{I}$ & 6 & 0 & 1 & 0 & 0 & 0 & $>96$ \\
\hline
\end{tabular}




\begin{tabular}{|l|r|l|r|l|l|l|l|}
\hline Total & 91 & & 20 & & 32 & & \\
\hline
\end{tabular}

For cattle, harvesting of young adults was consistent with a focus on meat production (Table 3). The presence on several distal limb bones of pathologies similar to those that develop on draught oxen, coupled with the high proportion of flint sickle blades and sickle blanks (35\%) in the lithic assemblage and the presence of several stone circular features, tentatively interpreted as the bases of silos, suggest intensive grain production at Marj Rabba aided by oxen traction (Price et al. 2013).

Table 3. Cattle suggested ages for Halstead's age classes (Halstead 1985). Suggested ages for last four categories: Young Adult $=3-5$ years; Adult $=5-10$ years; Old $=10-14$ years; Senile > 14 years.

\begin{tabular}{|l|r|r|r|}
\hline Age Class & MNE & \% Surviving & Est. Age \\
\hline A & 0 & 100 & $0-1$ Month \\
\hline B & 1 & 93 & $1-8$ Months \\
\hline C & 0 & 93 & $8-18$ Months \\
\hline D & 2 & 79 & $18-30$ Months \\
\hline E & 5 & 43 & $30-36$ Months \\
\hline F & 1 & 36 & Young Adult \\
\hline G & 1 & 29 & Adult \\
\hline H & 2 & 14 & Old \\
\hline I & 2 & 0 & Senile \\
\hline Total & 14 & & \\
\hline
\end{tabular}

Swine exploitation at Marj Rabba focused on domesticated pigs, with very little or no contribution from wild boar (Price et al. 2013). Mortality data indicate an intensive husbandry system that targeted animals less than one year old (Table 4). The early age at death stands in contrast to other Chalcolithic sites in the Middle East, where the majority 


\section{AUTHOR ACCEPTED MANUSCRIPT}

of pigs were slaughtered after eight months of age - e.g., mid-late $4^{\text {th }}$ millennium Hacinebi in southeastern Anatolia (Price 2016: 218), Çamlibel Tarlasi (Bartosiewicz et al. 2013), and "Early Chalcolithic" (late $6^{\text {th }}$ millennium) Tel Tsaf (Ben-Shlomo et al. 2009). Early slaughter potentially indicates a management system designed to raise and fatten pigs quickly, providing pork for the inhabitants of the site on a regular basis.

Table 4. Pig suggested ages for Lemoine et al.'s "simplified-A" age classes (Lemoine et al. 2014: 186).

\begin{tabular}{|l|r|r|r|}
\hline Age Class & MNE & \% Surviving & Est. Age (months) \\
\hline A & 3 & 94 & $<1$ \\
\hline B & 32 & 30 & $3-8$ \\
\hline C & 6 & 18 & $8-12$ \\
\hline D & 6 & 6 & $12-16$ \\
\hline E & 2 & $18-52$ \\
\hline F & 1 & 2 & $52-96$ \\
\hline G & 0 & 0 & $>96$ \\
\hline Total & 50 & 0 & \\
\hline
\end{tabular}

In sum, zooarchaeological, macrobotanical, and material culture records paint a picture of a community balancing its demands for the intensive production of grain and secondary products against an inherited tradition of risk-minimizing herding strategies. It remains ambiguous as to what role, if any, more mobile forms of pastoralism may have played. Similarly, while demographic data from pigs suggest an intensive management system, it is not understood how people at Marj Rabba managed food resources for these omnivores, which provided a sizable portion of the meat consumed at the settlement. 


\section{AUTHOR ACCEPTED MANUSCRIPT}

\section{The Environment of Marj Rabba}

The Lower Galilee is characterized by steep hills, typically less than 500 masl in height, and lies within the Mediterranean phytogeographic zone (Figure 2). The apex vegetation of this zone is dominated by woodlands/park forests of evergreen oak (Quercus calliprinos), deciduous oak (Quercus ithaburensis), and terebinth (Pistacia palaestina). These and other $\mathrm{C}_{3}$ plants provide the vast majority of plant biomass, although some $\mathrm{C}_{4}$ plants are also present (Hartman \& Danin 2010). While not extant today, low carbon isotopic values exhibited in aurochsen may indicate moderately dense forests existed in this region in the early Holocene (Makarewicz et al. 2016), although additional isotopic and paleoenvironmental data are needed to more fully explore this hypothesis.

The Galilee, like the rest of the Levant, is characterized by moderate seasonality, with hot and dry summers and cool, moist winters. Today, precipitation falls during the winter and early spring in amounts ranging from 500-1000 mm along an east-west and north-south cline. The highest precipitation levels are found in the north in the Upper Galilee, where elevations reach as high as 1000 masl (Ziv et al. 2014). The area around Marj Rabba, the Lower Galilee, receives around 500-700 mm per year.

During the Chalcolithic, the Mediterranean zone extended further south than at present. The environmental carbon and oxygen isotopic recorded in speleothems from Soreq Cave, located $25 \mathrm{~km}$ west of Jerusalem, indicate that the Chalcolithic was somewhat wetter during the Middle Holocene, with a local peak in humidity around 4500 cal. BC (Bar-Matthews \& Ayalon 2011). Similarly, Dead Sea pollen cores yielded high concentrations of $Q$. calliprinos and Q. ithaburensis; Litt et al. (2012: 100) contend that 
this indicates the presence of these oak species further south into the Judean Hills than at present. Isotopic analysis of snail shells dating to the Middle Holocene (c. 6500-3000 uncal. $\mathrm{BP}$ ) indicates that $\mathrm{C}_{3}$-dominated plant communities with rainfall above 300 $\mathrm{mm} /$ year existed, on average, about $20 \mathrm{~km}$ south of their current terminus (Goodfriend 1990).

Marj Rabba's location places it in relatively close proximity to other environmental zones that are markedly different from the Mediterranean vegetation of the Galilee. Today, Sudano-Zambezian vegetation dominates the most southern part of the Jordan River Valley (Danin 2004; Schiebel \& Litt 2018). Further north in the Ghor, and closer to Marj Rabba, mixed communities of Mediterranean and Saharo-Sudanian vegetation are present, with some flora typically found in an Irano-Turanian zone (Danin 2004). Additionally, the Ghor, which is the northern reach of the Great Rift Valley, represents a major depression in the landscape with elevations averaging -200 to $-300 \mathrm{~m}$ asl. Here, mean rainfall is typically less than $200 \mathrm{~mm} /$ year (Ziv et al. 2014; Schiebel \& Litt 2018), with $\mathrm{C}_{4}$ vegetation more prominent below the $300 \mathrm{~mm}$ isohyet (Goodfriend 1990). The Saharo-Sudanian and Sudan-Zambezian phytogeographic zones support a higher abundance of $\mathrm{C}_{4}$ flora, including grasses (Poaceae) and chenopods (Zohary 1982; Danin 1995).

\section{Carbon and Nitrogen Isotope Ecology}

Carbon isotopes shed light on plant ecology and, therefore, the diets of the animals who eat them. Several physiological and environmental variables influence floral carbon isotopic composition, including photosynthetic pathway, water availability, and 
canopy cover. $\mathrm{C}_{3}$ plants exhibit low $\delta^{13} \mathrm{C}$ values, globally averaging around $-26.5 \%$, compared to $\mathrm{C}_{4}$ plants, which average around -12\%o (Smith \& Epstein 1971). Under conditions of water stress, plant stomata close to conserve moisture, a process that reduces the conductivity of $\mathrm{CO}_{2}$ and, consequently, enriches leaf tissue in ${ }^{13} \mathrm{C}$ by as much as 3-6\% (Stewart et al. 1995; Hartman \& Danin 2010). Density of forest canopy cover and light intensity also influences the carbon isotopic composition of grasses, forbs, and arboreal taxa. The combination of decomposing plant litter releasing ${ }^{13} \mathrm{C}$-depleted $\mathrm{CO}_{2}$, the recycling of atmospheric $\mathrm{CO}_{2}$, and/or low light levels that reduce photosynthetic rate can lead to a depletion in ${ }^{13} \mathrm{C}$ by as much as $5 \%$ (Vogel 1978; Van der Merwe \& Medina 1991; Bonafini et al. 2013). Isotopic variation in the floral biome is incorporated into herbivore tissues with a roughly $+5 \%$ offset in bone collagen $\delta^{13} \mathrm{C}$ values relative to that of dietary intake (Koch et al. 1994).

The nitrogen isotopic composition of plants varies according to plant physiology, aridity, local source nitrogen pools, and plant part so that floral $\delta^{15} \mathrm{~N}$ values typically vary widely in semi-arid environments. Legumes and other plants that rely on symbiotic nitrogen-fixing bacteria are depleted in ${ }^{15} \mathrm{~N}$ compared to those that assimilate nitrogen from non-biological sources, although this pattern can be reversed depending on the ${ }^{15} \mathrm{~N}$ composition of the soil (DeNiro \& Epstein 1981). Plants growing in hot and arid environments exhibit higher $\delta^{15} \mathrm{~N}$ values due to the inhibition of biological fixation of atmospheric $\mathrm{N}_{2}$ - fixation discriminates against the heavier isotope (Bogaard et al. 2007). In the context of the southern Levant, plants in regions that receive around $500 \mathrm{~mm} / \mathrm{year}$ rainfall, such as the Lower Galilee, are depleted c. $3-5 \%$ in ${ }^{13} \mathrm{C}$ relative to environments that receive around $200 \mathrm{~mm} /$ year, such as the southern Jordan Valley (Hartman \& Danin 
2010: 845). Finally, floral growth in soils characterized by high nitrogen isotope ratios exhibits higher $\delta^{15} \mathrm{~N}$ values (Rennie et al. 1976). Higher soil $\delta^{15} \mathrm{~N}$ values can occur due to denitrification (Högberg 1990). On the other hand, the addition of exogenous nitrogen, such as manure, would increase floral $\delta^{15} \mathrm{~N}$ values due to the loss of ${ }^{14} \mathrm{~N}$ via gaseous ammonia that enriches the soil in ${ }^{15} \mathrm{~N}$ (Choi et al. 2006; Bogaard et al. 2007). Different plant tissues also exhibit different nitrogen isotope ratios due to fractionation during the uptake and assimilation of ammonia or nitrate, with progressive enrichment of ${ }^{15} \mathrm{~N}$ from roots to stems and leaves to seeds and fruits. Overall, seeds are enriched in ${ }^{15} \mathrm{~N}$ about 12\%o compared to leaves and stems (Yoneyama et al. 1991; Bogaard et al. 2007). Animal bone collagen is enriched approximately $3 \%$ in ${ }^{15} \mathrm{~N}$ and $1 \%$ in ${ }^{13} \mathrm{C}$ for each trophic step up the food chain, with herbivores displaying lower values than omnivores and carnivores (DeNiro \& Epstein 1981). Animals ingesting higher amounts of animal protein in their diet display higher $\delta^{15} \mathrm{~N}$ values. Similarly, suckling animals are enriched in ${ }^{15} \mathrm{~N}$ relative to their mothers since their diet consists entirely of milk (Fogel et al. 1989; Hedges \& Reynard 2007).

\section{Methods}

A total of 116 animal bones were sampled for carbon $\left(\delta^{13} \mathrm{C}\right)$ and nitrogen $\left(\delta^{15} \mathrm{~N}\right)$ isotopic analysis. Bones were identified on established morphological criteria as belonging to Ovis aries $(\mathrm{n}=16)$, Capra hircus $(\mathrm{n}=12)$, Bos taurus $(\mathrm{n}=39)$, Sus scrofa $(\mathrm{n}=40)$, and Gazella $(\mathrm{n}=9)$. Gazella gazella, the only species of gazelle to inhabit the Galilee today and throughout the Holocene, is a territorial animal than maintains a small 


\section{AUTHOR ACCEPTED MANUSCRIPT}

home range (Martin 2000: 22). Gazelle specimens were analyzed in order to characterize the carbon and nitrogen composition of vegetation surrounding Marj Rabba.

Bones were exported to the United States for zooarchaeological analysis, during which time samples were cut using a diamond-tipped Dremel drill at the Zooarchaeology Laboratory at Harvard University. All faunal remains were returned to Israel and are currently stored at the W.F. Albright Institute of Archaeological Research in Jerusalem.

Demineralization was carried out at the Archaeological Stable Isotopes Laboratory at Kiel University. Samples were demineralized in 0.5 M EDTA ( $\mathrm{pH}=7.5)$ following Tuross et al. (1988). Demineralized samples were then rinsed seven times in $\mathrm{dH}_{2} \mathrm{O}$, soaked in $0.1 \mathrm{M} \mathrm{NaOH}$ overnight at $4{ }^{\circ} \mathrm{C}$ to ensure removal of any residual humic acids, and then rinsed five more times in $\mathrm{dH}_{2} \mathrm{O}$. Samples were then sent for analysis to the Boston University Stable Isotope Laboratory. Samples were combusted at $1800^{\circ} \mathrm{C}$ in a Eurovector $\mathrm{CN}$ elemental analyzer, with $\mathrm{H}_{2} \mathrm{O}$ removed by a chemical trap. They were then introduced into a continuous flow GVI IsoPrime isotope-ratio mass spectrometer. For calibration, ${ }^{13} \mathrm{C}$ was calibrated against NBS 20 , NBS 21 , and NBS $22 ;{ }^{15} \mathrm{~N}$ was against atmospheric $\mathrm{N}_{2}$ and IAEA standards $\mathrm{N}-1, \mathrm{~N} 2$, and $\mathrm{N}-3$. One lab reference (peptone or glycine) was run per 10 samples to ensure machine accuracy and precision. Measurement error on these amino acids was $\pm 0.1 \%$ for $\delta^{13} \mathrm{C}$ and $\pm 0.4 \%$ for $\delta^{15} \mathrm{~N}$. After the data had been generated, we followed the recommendations of van Klinken (1999) and included for statistical analysis only those collagen samples yielding $\mathrm{C} / \mathrm{N}$ ratios of 2.9-3.6, \% $\mathrm{C}$ of $30-47 \%$, and $\% \mathrm{~N}$ of $10-18 \%$.

\section{Results}




\section{AUTHOR ACCEPTED MANUSCRIPT}

In total, 77 out of the original 116 samples yielded well-preserved collagen (Supporting Information 1; Table 5; Figure 3). Carbon isotope values for all samples ranged from -21.6 to $-14.1 \%$, with most specimens yield values between -21.6 and $18 \%$ indicating that most animals fed in a primarily $C_{3}$ biome. Gazelle $(n=4)$ on average $-19.2 \pm 0.9 \%$ in $\delta^{13} \mathrm{C}$ and were isotopically similar to goats $(\mathrm{n}=10 ;-19.4 \pm 0.3 \% \mathrm{o})(\mathrm{t}=$ $.414, \mathrm{df}=3.347, \mathrm{P}=.703)$ and sheep $(\mathrm{n}=10 ;-19.9 \pm 1.4 \%$ ). Removal of a single outlier measuring $-16.5 \%$ resulted in a lower mean value of $-20.2 \%$ for sheep. This was significantly lower than goats $(\mathrm{t}=2.86, \mathrm{df}=10.67, \mathrm{P}=.02)$.

Pigs $(\mathrm{n}=29 ;-19.4 \pm 0.7 \%$ ) were also similar in their carbon isotopic composition to sheep, goats, and gazelle $(\mathrm{t}=.571, \mathrm{df}=38.782, \mathrm{P}=.572)$. However, cattle ( $\mathrm{n}=24 ;-18.6 \pm 1.6 \%$ ) were significantly enriched in ${ }^{13} \mathrm{C}$ by $0.9 \%$ compared to all other ruminant species grouped together $(\mathrm{t}=2.73, \mathrm{df}=38.87, \mathrm{P}=.01)$. While this average enrichment is modest in magnitude, inspection of the data revealed that cattle exhibited a particularly wide range values $(-21.6$ to $-14.1 \%$ ), with one-third of sampled cattle exhibited $\delta^{13} \mathrm{C}$ values $>-18 \%$. These high $\delta^{13} \mathrm{C}$ values contrast with those of the other species, with the exception of the single outlier sheep noted above (Figure 4).

Herbivores from Marj Rabba exhibited relatively low variation in nitrogen isotopes ranging from ca. 5 to $7 \%$. Gazelle $(5.6 \pm 0.6 \%$ ) as well as domesticated goats $(6.0 \pm 0.9 \%)$, sheep $(5.9 \pm 1.3 \%$ ) , and cattle $(5.8 \pm 1.1 \%$ ) exhibited, on average, similar $\delta^{15} \mathrm{~N}$ values. A one-way ANOVA revealed no significance differences between the ruminants $(\mathrm{F}(3,44)=.18 ; \mathrm{P}=.91)$. However, pigs $(7.0 \pm 1.0 \%)$ were enriched in ${ }^{15} \mathrm{~N}$ by an average of $1.2 \%$ compared to the combined ruminant species $\delta^{15} \mathrm{~N}(\mathrm{t}=4.79, \mathrm{df}=60.0$, 
$\mathrm{P}<.01)$. A single outlier displaying a particularly high $\delta^{15} \mathrm{~N}$ value of $10.6 \%$ was from a juvenile pig.

Table 5. Summary statistics of carbon and nitrogen isotopic data from Marj Rabba.

\begin{tabular}{|l|l|l|l|}
\hline Taxon & $\mathbf{N}$ & Mean $\boldsymbol{\delta}^{\mathbf{1 3}} \mathbf{C} \pm \mathbf{1}$ sd (\%o) & Mean $\boldsymbol{\delta}^{\mathbf{1 5}} \mathbf{N} \pm \mathbf{1}$ sd (\%o) \\
\hline Bos taurus & 24 & $-18.55 \pm 1.56$ & $5.79 \pm 1.08$ \\
\hline Ovis aries & 9 & $-19.85 \pm 1.38$ & $5.93 \pm 1.26$ \\
\hline Capra hircus & 10 & $-19.44 \pm .34$ & $5.97 \pm .86$ \\
\hline Gazella gazella & 4 & $-19.23 \pm .90$ & $5.60 \pm .56$ \\
\hline Sus scrofa & 29 & $-19.44 \pm .65$ & $6.98 \pm 1.01$ \\
\hline
\end{tabular}

\section{Mobility and Diversified Husbandry Strategies for Sheep, Goats, and Cattle}

The carbon isotopic differences between sheep, goat, and cattle indicate dietary differences between these species. Turning first to the small sample of sheep and goats, slight differences in $\delta^{13} \mathrm{C}$ values suggest different dietary preferences or, potentially, the exploitation of different pastures. Notably, goats were isotopically similar to gazelle, which suggests that goats were locally pastured in the vicinity of Marj Rabba as part of a village-based pastoral strategy.

Sheep isotopic data show a different pattern. First, the presence of an outlier with a $\delta^{13} \mathrm{C}$ value of $-16.5 \%$ indicates a diet that included $\mathrm{C}_{4}$ plants and/or water-stressed $\mathrm{C}_{3}$ plants. This suggests access to non-local biomes - likely pasturing in the Jordan River Valley, as will be discussed for cattle below. Once, this outlier is removed, sheep are significantly depleted $.8 \%$ in $\delta^{13} \mathrm{C}$ relative to goats $(\mathrm{t}=2.86, \mathrm{df}=10.67, \mathrm{P}=.02)$. Sheep tend to consume more graze than browse relative to goats, and while grasses tend to exhibit higher $\delta^{13} \mathrm{C}$ values than browse, annuals can exhibit lower $\delta^{13} \mathrm{C}$ values than shrubs 
and trees (Hartman \& Danin 2010: Fig 4). Another explanation is that herders took flocks of sheep to moister pastures located at higher elevations during the drier summer months, a scenario consistent with Levy's (1983) hypothesis for seasonal caprine herding in the Chalcolithic Negev. The Upper Galilee, about 20-30 km north of Marj Rabba and where several Chalcolithic sites are located (Shalem 2008), represents the closest location with higher average rainfall. By pasturing sheep on pastures with more abundant vegetation, especially during crucial summer months, herders may have been attempting to improve wool quality or output. Dry seasons and corresponding graze shortages limit exogenous amino acid intake, leading to reductions in wool staple length and fiber diameter (e.g., Liu et al. 1998).

For cattle, the combination of a wide range in carbon isotope values and the high proportion of specimens exhibiting values greater than $-18 \%$ suggest two foddering/pasturing strategies were in use: one in which animals grazed locally, perhaps on field stubble as well as wild vegetation, and another that relied on higher amounts of $\mathrm{C}_{4}$ graze and, in at least some cases, utilized pastures located in warmer and drier landscapes. One can certainly explain at least some of the isotopic variation in cattle due to grazing these animals on local pastures with a higher relative abundance of $\mathrm{C}_{4}$ plants. Collection of winter fodder in mixed $\mathrm{C}_{3} / \mathrm{C}_{4}$ stands might also explain some of the variation. But at least a few of the cattle, along with the outlier sheep, most likely exploited pastures outside the Galilee region. This is especially the case for those exhibiting $\delta^{13} \mathrm{C}$ values greater than $-17 \%$,. Pastures that support higher density of ${ }^{13} \mathrm{C}$ enriched $\mathrm{C}_{4}$ plants and water stressed $\mathrm{C}_{3}$ graze were present in the Jordan Valley some 40km away. Moving cattle down to the Jordan Valley would probably take several days 
to one week, based on comparisons with $19^{\text {th }}$-century cattle drives in the American Southwest (Bell \& Haley 1932).

The decision to move cattle from Marj Rabba to the more arid environments that supported less productive pastures may have been linked to the numerous regionallyimportant settlements located in the Jordan Valley that would have served as hubs of ceremonial activity, exchange, and communication in the Chalcolithic world (Rowan \& Golden 2009: 16). Chalcolithic settlements in the Jordan Valley are unusual in that cattle were intensively exploited, demonstrated by the high proportion of Bos bones at Pella (30\%) and Abu Hamid (33\%) (Dollfus et al. 1988; Bourke et al. 2003). Later historical texts from the Levant and beyond depict cattle as valuable commodities that could be given as gifts, dowries, or bride prices, or taken as booty (Arbuckle 2014). Cattle were particularly high-value commodities among the elite from Anatolia to Egypt to Mesopotamia (Arbuckle 2014). Perhaps, then, the settlements in the Jordan Valley served as locations in which people from across the southern Levant met and, among other things, offered cattle as sacrifices, consumed them in feasts similar to the one found at Marj Rabba (Hill et al. 2016), or exchanged them for prestige objects or marital partners. If so, cattle may themselves be considered prestige objects - that is, beings uniquely situated to facilitate exchange in other prestige goods or as gifts accompanying marriage. We can, perhaps, draw rough parallels to the use of cattle among the Tiv, where Bohannan observed them exchanged almost exclusively for brass rods and other prestige goods (Bohannan 1955), or East African groups such as the Nuer, in which cattle function as bride-prices and facilitate many other forms of exchange (e.g., Hutchinson 1992). 


\section{Agricultural Intensification and Feeding Pigs}

Cross-culturally, pig husbandry strategies vary widely. They include, on one end of the spectrum, free-ranging with minimal human oversight and, on the other, penning reliant on direct feeding by humans with household food refuse and grain fodder. At Marj Rabba, the significant $1.2 \%$ enrichment in ${ }^{15} \mathrm{~N}$ visible in suids to herbivores suggests that pigs accessed either a ${ }^{15} \mathrm{~N}$-enriched plant food or ingested a higher proportion of animal protein in their diets. Interestingly, this pattern of higher nitrogen isotope ratios in pigs at Marj Rabba contrasts sharply with those observed for wild and domestic suids from other sites in the prehistoric Middle East, including Chalcolithic Çamlibel Tarlasi (Pickard et al. 2017), PPNA-PN Çayönü Tepesi (Pearson et al. 2013), and E-MPPNB Nevali Çori (Lösch et al. 2006), where suids exhibited lower mean $\delta^{15} \mathrm{~N}$ values than cattle and similar or lower values than sheep/goats. At these sites, zooarchaeologists interpreted these and other data as indications of free-ranging (Lösch et al. 2006; Pearson et al. 2013; Pickard et al. 2017).

One possible explanation for the higher $\delta^{15} \mathrm{~N}$ in the Marj Rabba pigs is that they consumed household leftovers ("slop") that contained at least some animal proteins in the form of dairy, meat, or feces. Alternatively, they may have been able to root for insects and annelids. Several scholars have put forth this as an explanation to account for higher $\delta^{15} \mathrm{~N}$ values in pigs (e.g., Hamilton \& Thomas 2012; Balasse et al. 2018: 83). Another possible explanation is that pigs consumed large amounts of hardwood nuts, which are high in crude protein. Mast-feeding systems, in which pigs are allowed to pasture seasonally in beech or oak woodlands, are well known from historical and modern 
ethnographic data in Europe (Hadjikoumis 2012; Halstead and Isaakidou 2011). The catchment area surrounding Marj Rabba likely included stands of evergreen (Quercus calliprinos) and deciduous oak (Quercus ithaburensis), both of which produce ripe fruit in the autumn. Ethnohistorical evidence from Greece indicates that acorns, especially of deciduous oak (anecdotally reported to preserve better) may have been collected in the autumn and used for fodder for penned pigs (Halstead and Isaakidou 2011:166).

A third possible explanation for the suid carbon and nitrogen isotopic patterns is that pigs consumed large volumes of grain, which is enriched ca.1-2\%o in nitrogen isotopes compared to other plant tissues (Bogaard et al. 2007). Ingestion of cereals grown in fertilized soils may have also contributed to nitrogen isotopic enrichment in pigs (Bogaard et al. 2007). Grain-feeding pigs as part of an intensive husbandry system would enable pigs to gain weight faster, achieve larger carcasses at slaughter, and produce larger litters (Halstead and Isaakidou 2011:166). Herders committed to creating a large supply of pork frequently devote a substantial portion of agricultural surplus to supporting pig fattening operations. In New Guinea, many highland villagers raise pigs on diets dominated by sweet potatoes cultivated by humans for the propose of pigfeed (see Hide 2003: 55-78). Penned "household pigs" in modern Greece are said to consume about as much grain as an adult human (Halstead and Isaakidou 2011:167). Similarly, late $3^{\text {rd }}$ millennium BC texts from Mesopotamia refer to so-called "grain-fed pigs" (šah-hi-a še), animals fattened on oats, bran, dates, and low-quality flour (Lion \& Michel 2006; Owen 2006). These texts also document pig feed deriving in part from spent brewing grain, indicating that pig husbandry can complement other food production activities (Lion \& Michel 2006: 94). 
While grain was unlikely to have been the sole component of pig diets, limited as it is in essential amino acids such as lysine, it may well have been the dominant source of caloric intake. Modern Western farmers typically supplement pig diets with animalprotein additives (fishmeal, bone meal, or whey) and/or soybeans to achieve the full component of amino acids (National Research Council 1998: 17-25). In traditional pig husbandry systems, many herders supplement an essentially vegetarian pig diet with annelids (worms) or insects which are collected for pigfeed (e.g., Hide 2003: 57) or whey protein leftover from dairy production (Halstead and Isaakidou 2011:167). Nevertheless, animal protein, while highly variable, typically constitutes a small proportion of pig diet (c. 10\% or less by dry weight). Moreover, vegetarian pig diets are possible as long as they contain high enough concentrations of essential amino acids (e.g., from legumes). Fully vegetarian diets have been shown to result in similar growth and carcass performance (Liesegang et al. 2002).

The isotopic data are not sufficient to test between these different hypotheses. It remains possible, perhaps likely, that pig herders at Marj Rabba pursued all three strategies: meat/milk supplemental feeding, acorn harvesting, and grain-foddering. Unfortunately, additional isotopic tests on seeds, which could test the grain-feeding hypothesis, are not possible given the low abundance and poor preservation of botanical remains at Marj Rabba (Graham 2018). The zooarchaeological and archaeological data, however, offer potential support to the grain-feeding hypothesis. Namely, the focused slaughter of 3-8-month-old pigs at Marj Rabba points to an intensive husbandry regime in which pigs achieved slaughter weight by the autumn or winter. Foddering with grain would allow pigs to grow and fatten quickly, reaching slaughter weight more quickly. 
Grain production appears to have been intensive at Marj Rabba. This is attested to by the abundance of sickle blades and blanks in the lithic assemblage and the presence of several circular architectural evidence interpreted as silos.

If grain foddering was a central component of pig husbandry at Marj Rabba and in the Levant more widely, it might explain why pig husbandry declined in the Bronze Age. Sheep, goats, and cattle contributed secondary products and, at least by the Late Bronze Age, embodied wealth (e.g., Sapir-Hen 2019). The investment of grain resources in pig husbandry, which would not produce wealth, may have fallen out of favor. The use of grain as a commodity may also have redirected attention away from pig husbandry (Redding 1992). Thus, the transformation of pigs into a meat source in competition with wealth production may explain why swine declined in the importance in the southern Levant during the Early Bronze Age, despite the long tradition of pig husbandry in that region.

\section{Security, Mobility, and Contradiction in Chalcolithic Economies}

The isotopic data from the animals at Marj Rabba reveal several dietary patterns that, when compared to standard zooarchaeological datasets, enrich our understanding of Chalcolithic livestock production in the Galilee. For one, the $\delta^{13} \mathrm{C}$ data suggest that while goats were raised in the environs of the site, herders took at least some sheep to pasturelands in the Jordan Valley and, potentially, the Upper Galilee. If so - and we stress the need for additional testing based on larger sample sizes - this differential treatment of sheep, when viewed alongside the demographic data, suggests that Chalcolithic herders adopted somewhat more specialized herding strategies to increase 


\section{AUTHOR ACCEPTED MANUSCRIPT}

the output of wool. This can be viewed as a small step on the road to more intensive fiber production in the Early Bronze Age.

The unexpectedly high $\delta^{13} \mathrm{C}$ values in about a third of the cattle remains and one sheep indicates unique foddering/pasturing strategies. At least some cattle spent significant time in the Jordan Valley. While mobile sheep/goat husbandry has already been hypothesized for the Chalcolithic (Levy 1983), mobile cattle husbandry has not been previously considered as part of agro-pastoralist management strategies. Why move cattle? We suspect the reason may have to do with their connection to elite prestige. In other words, similar to ivory, copper, and stone maceheads cattle may have been another prestige good exchanged between, and desired by, emerging elites or ritual leaders. As embodiments of wealth, it is not hard to imagine that keeping these animals fed, exchanging them with other communities for goods or people, and even rustling herds from other villages may have made cattle some of the most mobile elements of the Chalcolithic animal economy.

While cattle, sheep, and goats would continue to play vital roles in southern Levantine economies, the role of pigs would diminish during the Early Bronze Age (Allentuck 2013). Further data are needed to test between different hypotheses for pig feeding regimes in the Chalcolithic. However, if grain-foddering was a regular feature of pig husbandry in the Levant, it might help explain the decline of swine husbandry in the Early Bronze Age. That is, if pig husbandry increasingly became reliant on cereal fodder, it would have found itself in competition both with efforts to produce large surpluses of grain and the foddering of other animals. In this new mode of production based on animal wealth, cereal-foddering of pigs may have become a contradictory element of the animal 
economy. Additionally, pigs, lacking secondary products, could not possess the level of value that sheep, goat, cattle of grain could. Thus restricted from the sphere of commodities, pig husbandry became a victim of the secondary products revolution.

\section{Figure Captions}

Fig. 1 Map of the southern Levant showing sites mentioned in text and modern cities.

Fig. 2 Map of environmental vegetation zones of the southern Levant. Redrawn from Schiebel \& Litt (2018:579). M = Mediterranean; IT = Irano-Turanian; SA = SaharoArabian; $\mathbf{S}=$ Sudano-Zambesian. Mixed zones indicated by sub-dominant vegetation type in parentheses (e.g., $\mathbf{S A}(\mathbf{M})=$ Sudano-Zambesian dominant with Mediterranean).

Fig. 3 Carbon and nitrogen isotopic data for animals from Marj Rabba. Star-shaped icons and black lines indicate mean \pm one standard deviation for $\delta^{13} \mathrm{C}$ and $\delta^{15} \mathrm{~N}$ values for each taxon.

Fig. 4 K-Means Clustering of carbon and nitrogen isotopic data from cattle from Marj Rabba, using kmeans() function in $\mathrm{R}$ with $\mathrm{k}=2$. Star-shaped icons and black lines indicate mean \pm one standard deviation indicate calculated means of the two groups.

\section{References}




\section{AUTHOR ACCEPTED MANUSCRIPT}

Allentuck AE (2013) Human-Livestock Relations in the Early Bronze Age of the Southern Levant. Unpublished PhD Dissertation, University of Toronto

Allentuck AE and Rosen AM (2019) The Risky Business of Keeping Pigs during Period of Climatic Fluctation: A Case from the Mid-Holocene Near East. Journal of Archaeological Science: Reports 24: 939-945

Ambrose SH (1991) Effects of diet, climate and physiology on nitrogen isotope abundances in terrestrial foodwebs. Journal of Archaeological Science 18: 293 317

Arbuckle BS (2014) The Rise of Cattle Cultures in Bronze Age Anatolia. Journal of Eastern Mediterranean Archaeology \& Heritage Studies 2: 277-297

Balasse M, Cucchi T, Evin A, Bălăşescu A, Frémondeau D, and Horard-Herbin M-P (2018). Wild game or farm animal? Tracking human-pig relationships in ancient times through stable isotope analysis. In: Stépanoff C, Vigne J-D (eds.), Hybrid communities. Biosocial approaches to domestication and other trans-species relationships. Routledge, London, pp 81-96

Bar-Matthws M, Ayalon A, Gilmour M, Matthews A, Hawkesworth CJ (2003) Sea-land Oxygen Isotopic Relationships from Planktonic Foraminifera and Speleolthems in the Eastern Mediterranean Region and their Implications for Paleorainfall during Intergrlacial Intervals. Geochimica et Cosmochimica Acta 67: 3181-3199

Bar-Matthews M and Ayalon A (2011) Mid-Holocene climate variations revealed by high-resolution speleothem records from Soreq Cave, Israel and their correlation with cultural changes. The Holocene 21: 163-171 
Bartosiewicz L, Gillis R, Girdland-Fink L, Evin A, Cucchi T, Hoelzel AR, Vidarsdottir US, Dobney K, Larson G, and Schoop U-D (2013). Chalcolithic Pig Remains from Çamlıbel Tarlası, Central Anatolia. In: De Cupere B, Linseele V, HamiltonDyer S (eds.), Archaeozoology of the Near East X: Proceedings of the Tenth International Symposium on the Archaeozoology of South-Western Asia and Adjacent Areas. Ancient Near Eastern Studies Supplement 44. Peeters, Leuven, pp 101-120

Bell JG and Haley JE (1932) A Log of the Texas-California Cattle Trail, 1854, I. The Southwestern Historical Quarterly 35: 208-237

Ben-Shlomo D, Hill AC, and Garfinkel Y (2009) Feasting between the Revolutions: Evidence from Chalcolithic Tel Tsaf, Israel. Journal of Mediterranean Archaeology 22: 129-150

Bogaard A, Heaton THE, Poulton P, and Merbach I (2007) The impact of manuring on nitrogen isotope ratios in cereals: archaeological implications for reconstruction of diet and crop management practices. Journal of Archaeological Science 34: $335-343$

Bohannan P (1955) Some Principles of Exchange and Investment among the Tiv. American Anthropologist 57: 60-70

Bonafini M, Pellegrini M, Ditchfield P, and Pollard AM (2013) Investigation of the 'canopy effect' in the isotope ecology of temperate woodlands. Journal of Archaeological Science 40: 3926-3935 


\section{AUTHOR ACCEPTED MANUSCRIPT}

Bourke SJ (2001). The Chalcolithic Period. In: MacDonald B, Adams R, Bienkowski P (eds.), The Archaeology of Jordan. Sheffield Academic Press, Sheffield, pp 107163

Bourke SJ, Lovell J, Sparks RT, Seaton PL, Mairs LD, and Meadows J (2007) A Fourth Season of Renewed Excavation by the University of Sydney at Tulaylat alGhassul (1999). Annual of the Department of Antiquities of Jordan 51: 35-80

Bourke SJ, Sparks RT, McLaren B, Sowada K, Mairs LD, Meadows J, Hikade T, and Reade W (2003) Preliminary Report on the University of Sydney's Eighteenth and Nineteenth Seasons of Excavations at Pella (Tabaqat Fahl) in 1996/7. Annual of the Department of Antiquities of Jordan 47: 335-388

Choi WJ, Arshad MA, Chang SX, Kim TH (2006) Grain ${ }^{15} \mathrm{~N}$ of Crops Applied with Organic and Chemical Fertilizers in a Four-year Rotation. Plant and Soil 284: $165-174$

Commenge C, Alon D, Levy TE, and Kansa EC (2006). Gilat's Ceramics: Cognitive Dimensions of Pottery Production. In: Levy TE (ed.), Archaeology, Anthropology and Cult: The Sanctuary at Gilat, Israel. Equinox, London, pp 394-506

Danin A (1995). Flora and Vegetation of Israel and Adjacent Areas. In: Yom-Tov Y, Tchernov E (eds.), The Zoogeography of Israel. W. Junk Publishers, Dordrecht, pp 129-159

Danin A (2004) Distribution Atlas of Plants in the Flora Palaestina Area. Israel Academy of Sciences and Humanities, Jerusalem

DeNiro MJ and Epstein H (1978) Influence of Diet on the Distribution of Carbon Isotopes in Animals. Geochimica et Cosmochimica Acta 42: 495-506 


\section{AUTHOR ACCEPTED MANUSCRIPT}

DeNiro MJ and Epstein S (1981) Influence of Diet on the Distribution of Nitrogen Isotopes in Animals. Geochimica et Cosmochimica Acta 45: 341-351

Dollfus G, Kafafi Z, Rewerski N, Vaillant E, Coqueugniot E, Desse J, and Neef R (1988). Abu Hamid, An Early Fourth Millennium Site in the Jordan Valley. In: Garrard AN, Gebel HG (eds.), The Prehistory of Jordan. BAR International Series 396, Oxford, pp 567-601

Drabsch B (2015) The Mysterious Wall Paintings of Teleilat Ghassul, Jordan. In Context. Archaeopress. Monographs of the Sydney University Teleilat Ghassul Project 3, Sydney

Epstein C (1978) A New Aspect of Chalcolithic Culture. Bulletin of the American Schools of Oriental Research 229: 27-45

Evershed RP, Payne S, Sherratt A, Copley MS, Coolidge J, Urem-Kotsu D, Kotsakis K, Özdoğan M, Özdoğan AE, Nieuwenhuyse O, Akkermans PMMG, Bailey D, Andeescu R-R, Campbell S, Farid S, Hodder I, Yalman N, Özbaşaran M, Biçakci E, Garfinkel Y, Levy TE, and Burton MM (2008) Earliest date for milk use in the Near East and southeastern Europe linked to cattle herding. Nature 455: 528-531

Finkelstein I and Gophna R (1993) Settlement, demographic, and economic patterns in the highlands of Palestine in the Chalcolithic and Early Bronze periods and the beginning of urbanism. Bulletin of the American Schools of Oriental Research 1993: $1-22$

Fogel M, Tuross N, Owsley DW (1989) Nitrogen isotope tracers of human lactation in modern and archaeological populations. Annual Report to the Director, Geophysical Laboratory 1988-89, Carnegie Institute of Washington, pp 111-117 


\section{AUTHOR ACCEPTED MANUSCRIPT}

Gibson S and Rowan YM (2006) The Chalcolithic in the Central Highlands of Palestine:

A Reassessment Based on a New Examination of Khirbet es-Sauma'a. Levant 38: $85-108$

Golden J, Levy TE, and Hauptmann A (2001) Recent Discoveries Concerning Chalcolithic Metallurgy at Shiqmim, Israel. Journal of Archaeological Science 28: $951-963$

Goodfriend, GA (1990) Rainfall in the Negev Desert during the Middle Holocene, Based on ${ }^{13} \mathrm{C}$ of Organic Matter in Land Snail Shells. Quaternary Research 34: 186-197 Gopher A and Tsuk T (1996). The Chalcolithic Assemblages. In: Gopher A (ed.), The Nahal Qanah Cave: Earliest Gold in the Southern Levant. Monograph Series of the Institute of Archaeology. Tel Aviv University, Tel Aviv, pp 91-138

Graham P (2018). Using Archaeobotanical Remains to Model Social, Political, and Economic Changes during the Chalcolithic Period in the Southern Levant. In: Yasur-Landau A, Cline EH, Rowan Y (eds.), The Social Archaeology of the Levant: From Prehistory to the Present. Cambridge University Press, Cambridge, pp 146-159

Grant A (1982). The Use of Tooth Wear as a Guide to the Age of Domestic Ungulates.

In: Wilson B, Grigson C, Payne S (eds.), Ageing and Sexing Animal Bones from Archaeological Sites. BAR British Series 109, Oxford, pp 91-108

Grigson C (1987) Different Herding Strategies for Sheep and Goat in the Chalcolithic of Beersheva. Archaeozoologia 1: 115-126

Grigson C (1995). Cattle keepers of the northern Negev: Animal remains from the Chalcolithic site of Grar. In: Gilead I (ed.), Grar: A Chalcolithic site in the 


\section{AUTHOR ACCEPTED MANUSCRIPT}

northern Negev. Ben-Gurion University of the Negev Press, Beersheva, pp 377452

Grigson C (1998). Plough and pasture in the early economy of the southern Levant. In:

Levy TE (ed.), The archaeology of society in the Holy Land. Leicester University Press, London, pp 245-268

Grigson C (2006). Farming? Feasting? Herding? Large Mammals from the Chalcolithic of Gilat. In: Levy TE (ed.), Archaeology, Anthropology and Cult: The Sanctuary at Gilat, Israel. Equinox, London, pp 215-319

Hadjikoumis A (2012).Traditional pig herding practices in southwest Iberia: Questions of scale and zooarchaeological implications. Journal of Anthropological Archaeology 31:353-364

Halstead P and Isaakidou V (2011). Revolutionary Secondary Products: The Development and Significance of Milking, Animal-Traction and Wool-Gathering in Later Prehistoric Europe and the Near East. In: Wilkinson T, Sherratt S and Bennet J (eds.), Interweaving Worlds: Systemic Interactions in Eurasia, 7th to 1st Millennia BC. Oxbow Books, Oxford, pp 61-76

Halstead P (1985). A Study of Mandibular Teeth from Romano-British Contexts at Maxey. In: Pryor F, French C (eds.), Archaeology and Environment in the Lower Welland Valley. East Anglian Archaeology, Norwich, pp 214-219

Hamilton J, Hedges REM, and Robinson M (2009) Rooting for Pigfruit: Pig Feeding in Neolithic and Iron Age Britain Compared. Antiquity 83: 998-1011 


\section{AUTHOR ACCEPTED MANUSCRIPT}

Hamilton J and Thomas R (2012) Pannage Pulses and Pigs: Isotopic and Zooarchaeological Evidence for Changing Pig Management Practices in Later Medieval England. Medieval Archaeology 56: 234-359

Hartman G and Danin A (2010) Isotopic values of plants in relation to water availability in the Eastern Mediterranean region. Oecologia 162: 837-852

Hedges REM and Reynard L (2007) Nitrogen isotopes and the trophic level of humans in archaeology. Journal of Archaeological Science 34: 1240-1251

Hide R (2003) Pig Husbandry in New Guinea A Literature Review and Bibliography. Australian Centre for International Agricultural Research, Canberra

Hill AC (2011) Specialized Pastoralism and Social Stratification: Analysis of the Fauna from Chalcolithic Tel Tsaf, Israel. Unpublished PhD Dissertation, University of Connecticut

Hill AC, Price MD, and Rowan YM (2016) Feasting at Marj Rabba, an Early Chalcolithic Site in the Galilee. Oxford Journal of Archaeology 35: 127-140

Högberg, P (1990) Forests Losing Large Quantitites of Nitrogen Have Elevated ${ }^{15} \mathrm{~N}:{ }^{14} \mathrm{~N}$ Ratios. Oecologia 84: 229-231

Horwitz LK (2002) Fauna from the Wadi Raba Site of Abu Zureiq. Israel Exploration Journal 52: 167-178

Hutchinson S (1992) The cattle of money and the cattle of girls among the Nuer, 193083. American Ethnologist 19: 294-316

Ilan D and Rowan YM (2012) Deconstructing and Recomposing the Narrative of Spiritual Life in the Chalcolithic of the Southern Levant (4500-3600 B.C.E.). Archaeological Papers of the American Anthropological Association 21: 89-113 


\section{AUTHOR ACCEPTED MANUSCRIPT}

Ilan D and Rowan YM (2019) Expediting Reincarnation in the Fifth Millennium BCE:

Interpreting the Chalcolithic Ossuaries of the Southern Levant. Oxford Journal of Archaeology 38: 248-270

Joffe AH, Dessel JP, and Hallote RS (2001) The 'Gilat Woman': Female Iconography, Chalcolithic Cult, and the End of Southern Levantine Prehistory. Near Eastern Archaeology 64: 8-23

Kerner S (2010) Craft Specialisation and Its Relation with Social Organisation in the Late 6th to Early 4th Millennium BCE of the Southern Levant. Paléorient 36: 179-198

Koch PL, Fogel ML, and Tuross N (1994). Tracing the diet of fossil animals using stable isotopes. In: Lajtha K, Michener RH (eds.), Stable Isotopes in Geology and Environmental Science. Blackwell, Oxford, pp 63-92

Lemoine X, Zeder MA, Bishop KJ, and Rufolo SJ (2014) A new system for computing dentition-based age profiles in Sus scrofa. Journal of Archaeological Science 47: $179-193$

Levy TE (1983) The Emergence of Specialized Pastoralism in the Southern Levant. World Archaeology 15: 15-36

Levy TE (1992). Transhumance, Subsistence, and Social Evolution in the Northern Negev. In: Bar-Yosef O, Khazanov A (eds.), Pastoralism in the Levant. Prehistory Press, Madison (WI), pp 65-82

Levy TE (1998). Cult, Metallurgy and Rank Societies - Chalcolithic Period (ca. 45003500 BCE). In: Levy TE (ed.), The Archaeology of Society in the Holy Land. Leicester University Press, London, pp 226-244 


\section{AUTHOR ACCEPTED MANUSCRIPT}

Levy TE (2006). Conclusion: The Evolution of a Levantine Prehistoric Regional Cult

Center. In: Levy TE (ed.), Archaeology, Anthropology and Cult: The Sanctuary at Gilat, Israel. Equinox, London, pp 831-848

Levy TE, Conner W, Rowan YM, and Alon D (2006). The Intensification of Production at Gilat: Textile Production. In: Levy TE (ed.), Archaeology, Anthropology and Cult: The Sanctuary at Gilat, Israel. Equinox, London, pp 705-738

Liesegang A, Bürgi E, Sassi M-L Risteli J, Wanner M (2002) Influence of a Vegetarian Diet verses a Diet with Fishmeal on Bone in Growing Pigs. Journal of Veterinary Medicine 49: 230-238

Lion B and Michel C (2006). L'Élevage des Porcs en Haute Mésopotamie, Syrie et Transtigrine au Debut du IIe Millénaire. In: Lion B, Michel C (eds.), De la Domestication au Tabou. De Boccard, Paris, pp 89-101

Litt T, Ohlwein C, Neumann FH, Hense A, and Stein M (2012) Holocene climate variability in the Levant from the Dead Sea pollen record. Quaternary Science Reviews 49: 95-105

Liu SM, Mata G, O’Donoghue H, and Masters G (1998) The influence of live weight, live-weight change and diet on protein synthesis in the skin and skeletal muscle in young Merino sheep. British Journal of Nutrition 79: 267-274

Lösch S, Grupe G, and Peters J (2006) Stable Isotopes and Dietary Adaptations in Humans and Animals at Pre-Pottery Neolithic Nevalı Çori, Southeast Anatolia. American Journal of Physical Anthropology 131: 181-193

Lovell $\mathbf{J}$ (2010) Community is Cult, Cult is Community: Weaving the Web of Meanings for the Chalcolithic. Paléorient 36: 103-122 
Makarewicz C, Horwitz L, and Goring-Morris AN (2016) Local adoption of animal husbandry in the southern Levant: An isotopic perspective from the Pre-Pottery Neolithic B funerary site of Kfar HaHoresh. Environmental Archaeology 21: 199213

Makarewicz C and Tuross N (2012) Finding fodder and Tracking Transhumance: Isotopic Detection of Goat Domestication Processes in the Near East. Current Anthropology 53: 495-505

Marom N and Bar-Oz G (2013) The Prey Pathway: A Regional History of Cattle (Bos taurus) and Pig (Sus scrofa) Domestication in the Northern Jordan Valley, Israel. PLoS ONE 8: 1-13

Martin, L (2000) Gazelle (Gazella spp.) Behavioural Ecology: Predicting Animal Behaviour for Prehistoric Environments in South-Wet Asia. Journal of Zoology $250: 13-30$

National Research Council (1998) Nutrient Requirements of Swine, $10^{\text {th }}$ edition. National Academy Press, Washington, DC

Notroff J, Schmidt K, Siegel U, and Khalil L (2014) Reconstructing networks, linking spaces - the view from the Aqaba region (Jordan). Levant 46: 249-267

Owen DI (2006). Pigs and Pig By-Products at Garsana in the Ur III Period. In: Lion B, Michel C (eds.), De la Domestication au Tabou. De Boccard, Paris, pp 75-87 Payne S (1972). On the Interpretation of Bone Samples from Archaeological Sites. In: Higgs E (ed.), Papers in Economic Prehistory. Cambridge University Press, Cambridge, pp 65-81 


\section{AUTHOR ACCEPTED MANUSCRIPT}

Payne S (1973) Kill-off Patterns in Sheep and Goats: The Mandibles from Aşvan Kale. Anatolian Studies 23: 281-303

Pearson J, Grove M, Özbek M, and Hongo H (2013) Food and social complexity at Çayönü Tepesi, southeastern Anatolia: Stable isotope evidence of differentiation in diet according to burial practice and sex in the early Neolithic. Journal of Anthropological Archaeology 32: 180-189

Pickard C, Schoop U-D, Bartosiewicz L, Gillis R, and Sayle KL (2017) Animal keeping in Chalcolithic north-central Anatolia: what can stable isotope analysis add? Archaeological and Anthropological Sciences 9: 1349-1362

Price MD (2016) Pigs and Power: Pig Husbandry in Northern Mesopotamia during the Emergence of Social Complexity (6500-2000 BC). Unpublished $\mathrm{PhD}$ Dissertation, Harvard University

Price MD, Buckley M, Rowan YM, and Kersel M (2013) Animal Management Strategies during the Chalcolithic in the Lower Galilee: New Data from Marj Rabba. Paléorient 39: 183-200

Price MD, Hill AC, Rowan YM, and Kersel M (2016) Gazelles and Chalcolithic Ritual: A Case Study from Marj Rabba. Bulletin of the American Schools of Oriental Research 376: 7-27

Redding R (1981) Decision Making in Subsistence Herding of Sheep and Goats in the Middle East. Unpublished PhD Dissertation, University of Michigan Redding R (1992) Egyptian Old Kingdom Patterns of Animal Use and the Value of Faunal Data in Modeling Socioeconomic Systems. Paléorient 18: 99-107 


\section{AUTHOR ACCEPTED MANUSCRIPT}

Rennie DA, Paul EA, and Johns LE (1976) Natural Nitrogen-15 Abundance of Soil and Plant Samples. Canadian Journal of Soil Science 56: 43-50

Riehl, S (2008) Climate and Agriculture in the Ancient Near East: A Synthesis of the Archaeobotanical and Stable Carbon Isotope Evidence. Vegetation History and Archaeobotany 17 (Supp 1): S43-S51

Rowan YM and Golden J (2009) The Chalcolithic Period of the Southern Levant: A Synthetic Review. Journal of World Prehistory 22: 1-92

Rowan YM and Ilan D (2007). The Meaning of Ritual Diversity of the Chalcolithic of the Southern Levant. In: Barrowclough D, Malone C (eds.), Cult in context: Reconsidering ritual in archaeology. Oxbow Books, Oxford pp 249-254

Rowan YM and Kersel M (2014). New Perspectives on the Chalcolithic Period in the Galilee: Investigations at the Site of Marj Rabba. In: Spencer JR, Mullins RA, Brody AJ (eds.), Material Culture Matters: Essays on the Archaeology of the Southern Levant in Honor of Seymour Gitin. Eisenbrauns, Winona Lake (IN), pp $221-238$

Sapir-Hen L (2019) Late Bronze and Iron Age Livestock of the Southern Levant: Their Economic and Symbolic Roles. Tel Aviv 46: 227-236

Schiebel V (2013) Vegetation and Climate History of the Southern Levant during the last 30,000 years based on Palynological Investigation. Unpublished $\mathrm{PhD}$ Dissertation, Bonn University

Schiebel V and Litt T (2018) Holocene Vegetation History of the Southern Levant Based on a Pollen Record from Lake Kinneret (Sea of Galilee), Israel. Vegetation History and Archaeobotany 27: 577-590 


\section{AUTHOR ACCEPTED MANUSCRIPT}

Shalem D (2008). The Upper and Lower Galilee in the Late Chalcolithic Period. In: Bar S (ed.), In the Hill country, and in the Shephelah, and in the Arabah (Joshua 12, 8). Studies and researches presented to Adam Zertal in the 30th anniversary of the Manasseh Hill-country survey. Ariel Publishing House (Hebrew), Jerusalem, pp $99-110$

Shalem D, Gal Z, and Smithline H (2013) Peqi'in - A Late Chalcolithic Burial Site, Upper Galilee, Israel. Kinneret Academic College, Jerusalem

Sherratt A (1983) The Secondary Products Revolution of Animals in the Old World. World Archaeology 15: 90-104

Smith BN and Epstein S (1971) Two categories of 13C/12C ratios for higher plants. Plant Physiology 47: 380-384

Smith PEL, Gopher A, and Netta L-T (2003) Dental Evidence for Dietary Practices in the Chalcolithic Period: The Findings from a Burial Cave in Peqi' in (Northern Israel). Paléorient 29: 121-134

Stewart GR, Turnbull MH, Schmidt S, and Erskine PD (1995) 13C Natural Abundance in Plant Communities Along a Rainfall Gradient: A Biological Integrator of Water Availability. Australian Journal of Plant Physiology 22: 51-55

Tuross N, Fogel ML, and Hare PE (1988) Variability in the preservation of the isotopic composition of collagen from fossil bone. Geochimica et Cosmochimica Acta 52: 929-935

Urban TA, Rowan YM, and Kersel M (2014) Ground-Penetrating Radar Investigations at Marj Rabba, a Chalcolithic Site in the Lower Galilee of Israel. Journal of Archaeological Science 46: 96-106 
Van der Merwe NJ and Medina E (1991) The Canopy Effect, Carbon Isotope Ratios and Foodwebs in Amazonia. Journal of Archaeological Science 18: 249-259 van Klinken GJ (1999) Bone collagen quality indicators for palaeo- dietary and radiocarbon measurements. Journal of Archaeological Science 26: 687-685

Vigne J-D and Helmer D (2007) Was milk a "secondary product" in the Old World Neolithisation process? Its role in the domestication of cattle, sheep and goats. Anthropozoologica 42: 9-40

Vogel JC (1978) Recycling of CO2 in a forest environment. Oecologia Plantarum 13: 8994

Yoneyama T, Omata T, Nakata S, and Yazak J (1991) Fractionation of Nitrogen Isotopes during the Uptake and Assimilation of Ammonial by Plants. Plant Cell Physiology 32: 1211-1217

Ziv B, Saaroni H, Pargament R, Harpaz T, and Alpert P (2014) Trends in rainfall regime over Israel, 1975-2010, and their relationship to large-scale variability. Regional Environmental Change 14: 1751-1764

Zohary M (1982) Vegetation of Israel and Adjacent Areas. Beihefte zum Tübinger Atlas des Vorderen Orients. Reihe A, Naturwissenschaft. Dr. Ludwig Reichert, Wiesbaden 
Appendix. Isotopic data from Marj Rabba. Shaded cells not included in analysis due to poor collagen preservation. For mandibles, only bone was sampled. Note: MC34 = Metacarpal 3-4, MT34 = Metatarsal 3-4, MP34 = Metapodial 3-4.

\begin{tabular}{|c|c|c|c|c|c|c|c|c|c|}
\hline Lab ID & $\begin{array}{l}\text { Taxo } \\
\text { n }\end{array}$ & $\begin{array}{l}\text { Loc } \\
\text { us }\end{array}$ & $\begin{array}{l}\delta^{13} \\
C\end{array}$ & $\% \mathrm{C}$ & $\begin{array}{l}\delta^{15} \\
N\end{array}$ & $\begin{array}{l}\% \\
\mathbf{N}\end{array}$ & $\begin{array}{l}\mathrm{C} / \\
\mathrm{N}^{*}\end{array}$ & Element & Age Info.** \\
\hline 13368 & Bos & $\begin{array}{l}111 \\
\mathrm{~A}\end{array}$ & $\begin{array}{l}- \\
20 . \\
1\end{array}$ & 35.8 & 4.6 & $\begin{array}{l}13 . \\
0\end{array}$ & 3.2 & Ilium Shaft & \\
\hline 12936 & Bos & $\begin{array}{l}121 \\
\mathrm{~A}\end{array}$ & $\begin{array}{l}21 . \\
6\end{array}$ & 36.3 & 4.7 & $\begin{array}{l}12 . \\
7\end{array}$ & 3.4 & MC34 Shaft & \\
\hline 15524 & Bos & $\begin{array}{l}322 \\
\text { B }\end{array}$ & $\begin{array}{l}- \\
17 . \\
6\end{array}$ & 36.8 & 5.0 & $\begin{array}{l}13 . \\
6\end{array}$ & 3.2 & Thor. Vert. & \\
\hline 11170 & Bos & $\begin{array}{l}304 \\
\text { B }\end{array}$ & $\begin{array}{l}- \\
20 . \\
0\end{array}$ & 37.4 & 5.8 & 14. & 3.1 & Calcaneus & \\
\hline 11355 & Bos & $\begin{array}{l}318 \\
\mathrm{~B} \\
\end{array}$ & $\begin{array}{l}- \\
16 . \\
8\end{array}$ & 37.4 & 6.6 & $\begin{array}{l}14 . \\
5 \\
\end{array}$ & 3.0 & $\begin{array}{l}\text { Humerus } \\
\text { Shaft }\end{array}$ & \\
\hline 11075 & Bos & $\begin{array}{l}312 \\
\mathrm{~B}\end{array}$ & $\begin{array}{l}- \\
17 . \\
1\end{array}$ & 37.7 & 7.2 & $\begin{array}{l}14 . \\
4\end{array}$ & 3.1 & $\begin{array}{l}\text { Mand. w/o } \\
\text { Teeth }\end{array}$ & \\
\hline 11088 & Bos & $\begin{array}{l}312 \\
B\end{array}$ & $\begin{array}{l}17 . \\
5\end{array}$ & 38.2 & 5.6 & $\begin{array}{l}14 . \\
1\end{array}$ & 3.2 & Ds. Radius & Fused \\
\hline 12694 & Bos & $\begin{array}{l}119 \\
\mathrm{~A}\end{array}$ & $\begin{array}{l}- \\
18 . \\
3\end{array}$ & 38.3 & 4.8 & $\begin{array}{l}14 . \\
6 \\
\end{array}$ & 3.1 & Tibia Shaft & \\
\hline 15305 & Bos & $\begin{array}{l}312 \\
\mathrm{~B}\end{array}$ & $\begin{array}{l}- \\
19 . \\
6\end{array}$ & 38.3 & 4.5 & $\begin{array}{l}14 . \\
4\end{array}$ & 3.1 & Ds. Radius & Unfused \\
\hline 12235 & Bos & $\begin{array}{l}166 \\
\text { A }\end{array}$ & $\begin{array}{l}- \\
19 . \\
6\end{array}$ & 38.4 & 5.6 & $\begin{array}{l}14 . \\
5\end{array}$ & 3.1 & $\begin{array}{l}\text { Humerus } \\
\text { Shaft }\end{array}$ & Fused (Ds.) \\
\hline 14241 & Bos & $\begin{array}{l}353 \\
B\end{array}$ & $\begin{array}{l}- \\
18 . \\
6\end{array}$ & 38.6 & 6.1 & $\begin{array}{l}14 . \\
6\end{array}$ & 3.1 & $\begin{array}{l}\text { Mand. w/o } \\
\text { Teeth }\end{array}$ & Unfused \\
\hline 11001 & Bos & $\begin{array}{l}314 \\
B\end{array}$ & $\begin{array}{l}- \\
19 . \\
2\end{array}$ & 38.9 & 5.2 & $\begin{array}{l}14 . \\
9\end{array}$ & 3.1 & MP34 Shaft & \\
\hline
\end{tabular}




\begin{tabular}{|c|c|c|c|c|c|c|c|c|c|}
\hline 11192 & Bos & $\begin{array}{l}312 \\
\mathrm{~B}\end{array}$ & $\begin{array}{l}- \\
14 . \\
1\end{array}$ & 39.0 & 8.9 & $\begin{array}{l}15 . \\
0\end{array}$ & 3.0 & MP34 Shaft & \\
\hline 14232 & Bos & $\begin{array}{l}360 \\
B\end{array}$ & $\begin{array}{l}- \\
19 . \\
4\end{array}$ & 39.4 & 5.9 & $\begin{array}{l}15 . \\
0\end{array}$ & 3.1 & Px. Radius & Fused \\
\hline 12487 & Bos & $\begin{array}{l}556 \\
\mathrm{C}\end{array}$ & $\begin{array}{l}19 . \\
5\end{array}$ & 39.5 & 6.3 & $\begin{array}{l}14 . \\
7\end{array}$ & 3.1 & MC34 Shaft & \\
\hline $\begin{array}{l}12487 \\
\text { (rep.) }\end{array}$ & - & - & $\begin{array}{l}- \\
18 . \\
2\end{array}$ & 40.4 & 5.9 & $\begin{array}{l}15 . \\
2\end{array}$ & 3.1 & - & 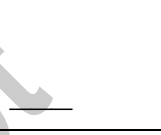 \\
\hline 14551 & Bos & $\begin{array}{l}385 \\
\text { B }\end{array}$ & $\begin{array}{l}17 . \\
0\end{array}$ & 39.9 & 5.3 & $\begin{array}{l}14 . \\
7\end{array}$ & 3.2 & Ds. Humerus & Fused \\
\hline 14405 & Bos & $\begin{array}{l}375 \\
\mathrm{~B} \\
\end{array}$ & $\begin{array}{l}- \\
18 . \\
8\end{array}$ & 40.1 & 7.0 & $\begin{array}{l}15 . \\
6\end{array}$ & 3.0 & Ds. Radius & Unfused \\
\hline 14321 & Bos & NA & $\begin{array}{l}- \\
20 . \\
5\end{array}$ & 40.3 & 4.3 & $\begin{array}{l}15 . \\
5\end{array}$ & 3.0 & $\begin{array}{l}\text { Humerus } \\
\text { Shaft }\end{array}$ & Fused \\
\hline 11321 & Bos & $\begin{array}{l}314 \\
\text { B }\end{array}$ & $\begin{array}{l}17 . \\
3\end{array}$ & 40.4 & 6.2 & $\begin{array}{l}15 . \\
4\end{array}$ & 3.1 & $\begin{array}{l}\text { Humerus } \\
\text { Shaft }\end{array}$ & \\
\hline 12237 & Bos & $\begin{array}{l}321 \\
\text { B }\end{array}$ & $\begin{array}{l}17 . \\
5\end{array}$ & 40.6 & 4.7 & $\begin{array}{l}15 . \\
3\end{array}$ & 3.1 & Thor. Vert & \\
\hline 10237 & Bos & $\begin{array}{l}322 \\
\mathrm{~B}\end{array}$ & $\begin{array}{l}19 . \\
8\end{array}$ & 40.6 & 7.2 & $\begin{array}{l}15 . \\
8\end{array}$ & 3.0 & MT34 Shaft & \\
\hline 14029 & Bos & $\begin{array}{l}364 \\
\text { B }\end{array}$ & $\begin{array}{l}- \\
18 . \\
3\end{array}$ & 40.7 & 6.4 & $\begin{array}{l}15 . \\
3\end{array}$ & 3.1 & MT34 Shaft & Fused \\
\hline 12486 & Bos & $\begin{array}{l}556 \\
\mathrm{C}\end{array}$ & $\begin{array}{l}- \\
18 . \\
8\end{array}$ & 42.7 & 5.2 & $\begin{array}{l}16 . \\
3\end{array}$ & 3.0 & MC34 Shaft & \\
\hline 11784 & $\begin{array}{l}\text { Capr } \\
\mathrm{a}\end{array}$ & $\begin{array}{l}385 \\
\mathrm{~B} \\
\end{array}$ & $\begin{array}{l}- \\
19 . \\
3\end{array}$ & 37.7 & 6.2 & $\begin{array}{l}14 . \\
5\end{array}$ & 3.0 & Ds. Tibia & Fused \\
\hline 12742 & $\begin{array}{l}\text { Capr } \\
\text { a }\end{array}$ & $\begin{array}{l}121 \\
\mathrm{~A}\end{array}$ & $\begin{array}{l}19 . \\
1\end{array}$ & 37.8 & 5.5 & $\begin{array}{l}14 . \\
1\end{array}$ & 3.1 & Ds. Humerus & Fused \\
\hline 10295 & $\begin{array}{l}\text { Capr } \\
\text { a }\end{array}$ & $\begin{array}{l}323 \\
\mathrm{~B}\end{array}$ & $\begin{array}{l}19 . \\
2\end{array}$ & 38.1 & 4.4 & $\begin{array}{l}14 . \\
3\end{array}$ & 3.1 & Ds. Humerus & Fusing \\
\hline 10116 & Capr & 319 & - & 39.0 & 6.0 & 14. & 3.1 & Ds. Tibia & Fused \\
\hline
\end{tabular}




\begin{tabular}{|c|c|c|c|c|c|c|c|c|c|}
\hline & $\mathrm{a}$ & B & $\begin{array}{l}19 . \\
1\end{array}$ & & & 9 & & & \\
\hline 13444 & $\begin{array}{l}\text { Capr } \\
\text { a }\end{array}$ & $\begin{array}{l}107 \\
\text { A }\end{array}$ & $\begin{array}{l}- \\
19 . \\
9\end{array}$ & 39.1 & 6.7 & $\begin{array}{l}15 . \\
1\end{array}$ & 3.0 & Px. Radius & Fused \\
\hline 13203 & $\begin{array}{l}\text { Capr } \\
\text { a }\end{array}$ & $\begin{array}{l}117 \\
\mathrm{~A}\end{array}$ & $\begin{array}{l}19 . \\
5\end{array}$ & 39.7 & 4.8 & $\begin{array}{l}15 . \\
3\end{array}$ & 3.0 & Ds. Humerus & Fused \\
\hline 10443 & $\begin{array}{l}\text { Capr } \\
\text { a }\end{array}$ & $\begin{array}{l}314 \\
\text { B }\end{array}$ & $\begin{array}{l}- \\
19 . \\
0\end{array}$ & 40.0 & 6.5 & $\begin{array}{l}15 . \\
4\end{array}$ & 3.0 & Ds. Humerus & Fused \\
\hline 11099 & $\begin{array}{l}\text { Capr } \\
\text { a }\end{array}$ & $\begin{array}{l}314 \\
\text { B }\end{array}$ & $\begin{array}{l}- \\
19 . \\
7\end{array}$ & 40.2 & 7.1 & $\begin{array}{l}15 . \\
7\end{array}$ & 3.0 & Ds. Humerus & Fused \\
\hline 13351 & $\begin{array}{l}\text { Capr } \\
\text { a }\end{array}$ & $\begin{array}{l}107 \\
\text { A }\end{array}$ & $\begin{array}{l}- \\
19 . \\
9\end{array}$ & 40.2 & 5.9 & $\begin{array}{l}15 . \\
6\end{array}$ & 3.0 & Ds. Humerus & Fused \\
\hline 12613 & $\begin{array}{l}\text { Capr } \\
\text { a }\end{array}$ & $\begin{array}{l}556 \\
\mathrm{C}\end{array}$ & $\begin{array}{l}- \\
19 . \\
7\end{array}$ & 40.4 & 6.6 & $\begin{array}{l}15 . \\
8\end{array}$ & 3.0 & Radius Shaft & $\begin{array}{l}\text { Fused (Px.); } \\
\text { Unfused } \\
\text { (Ds.) }\end{array}$ \\
\hline 11463 & $\begin{array}{l}\text { Gaze } \\
\text { lla }\end{array}$ & $\begin{array}{l}316 \\
\text { B }\end{array}$ & $\begin{array}{l}- \\
20 . \\
1\end{array}$ & 38.0 & 6.4 & $\begin{array}{l}13 . \\
7\end{array}$ & 3.2 & Ds. Humerus & Fusing \\
\hline 11340 & $\begin{array}{l}\text { Gaze } \\
\text { lla }\end{array}$ & $\begin{array}{l}318 \\
\mathrm{~B} \\
\end{array}$ & $\begin{array}{l}- \\
18 . \\
5\end{array}$ & 40.1 & 5.4 & $\begin{array}{l}15 . \\
4\end{array}$ & 3.0 & MT34 Shaft & \\
\hline 10214 & $\begin{array}{l}\text { Gaze } \\
\text { lla }\end{array}$ & $\begin{array}{l}318 \\
\mathrm{~B}\end{array}$ & $\begin{array}{l}- \\
9 \\
9\end{array}$ & 40.2 & 5.5 & $\begin{array}{l}15 . \\
4\end{array}$ & 3.0 & Ds. Tibia & Fused \\
\hline 13389 & $\begin{array}{l}\text { Gaze } \\
\text { lla }\end{array}$ & $\begin{array}{l}109 \\
\text { A }\end{array}$ & $\begin{array}{l}18 . \\
4\end{array}$ & 40.2 & 5.1 & $\begin{array}{l}15 . \\
8\end{array}$ & 3.0 & MC34 Shaft & \\
\hline 1389 & Ovis & $\begin{array}{l}378 \\
\mathrm{~B} \\
\end{array}$ & $\begin{array}{l}- \\
21 . \\
3\end{array}$ & 30.8 & 4.0 & $\begin{array}{l}11 . \\
0\end{array}$ & 3.3 & Ds. Humerus & Fused \\
\hline 14065 & Ovis & $\begin{array}{l}365 \\
B \\
\end{array}$ & $\begin{array}{l}- \\
16 . \\
5\end{array}$ & 36.5 & 8.8 & $\begin{array}{l}13 . \\
7\end{array}$ & 3.1 & Ds. Tibia & Fused \\
\hline 13373 & Ovis & $\begin{array}{l}111 \\
\text { A }\end{array}$ & $\begin{array}{l}- \\
21 . \\
2\end{array}$ & 36.9 & 5.7 & $\begin{array}{l}12 . \\
7\end{array}$ & 3.4 & Px. Radius & Fused \\
\hline 12674 & Ovis & $\begin{array}{l}575 \\
\mathrm{C}\end{array}$ & $\begin{array}{l}20 . \\
1\end{array}$ & 37.1 & 7.0 & $\begin{array}{l}14 . \\
3\end{array}$ & 3.0 & Px. Radius & Fused \\
\hline 13586 & Ovis & $\begin{array}{l}331 \\
\text { B }\end{array}$ & $-\overline{20 .}$ & 38.8 & 5.3 & $\begin{array}{l}14 . \\
9\end{array}$ & 3.0 & Ds. Humerus & Fused \\
\hline
\end{tabular}




\begin{tabular}{|c|c|c|c|c|c|c|c|c|c|}
\hline & & & 4 & & & & & & \\
\hline 13778 & Ovis & $\begin{array}{l}366 \\
\mathrm{~B} \\
\end{array}$ & $\begin{array}{l}19 . \\
7\end{array}$ & 39.1 & 6.0 & $\begin{array}{l}15 . \\
0\end{array}$ & 3.0 & Ds. Tibia & Fused \\
\hline $\begin{array}{l}13778 \\
\text { (rep.) }\end{array}$ & - & - & $\begin{array}{l}- \\
19 . \\
6\end{array}$ & 39.8 & 5.9 & $\begin{array}{l}15 . \\
2\end{array}$ & 3.1 & - & - \\
\hline 13537 & Ovis & $\begin{array}{l}331 \\
\text { B }\end{array}$ & $\begin{array}{l}- \\
20 . \\
6\end{array}$ & 39.5 & 5.5 & $\begin{array}{l}15 . \\
0\end{array}$ & 3.1 & Ds. Humerus & Fused \\
\hline 13006 & Ovis & $\begin{array}{l}113 \\
\mathrm{~A}\end{array}$ & $\begin{array}{l}- \\
18 . \\
9\end{array}$ & 39.5 & 5.2 & $\begin{array}{l}15 . \\
5\end{array}$ & 3.0 & Px. Radius & Fused \\
\hline 14592 & Ovis & $\begin{array}{l}554 \\
\mathrm{C}\end{array}$ & $\begin{array}{l}20 . \\
2\end{array}$ & 40.0 & 5.9 & $\begin{array}{l}15 . \\
4\end{array}$ & 3.0 & Ds. Humerus & Fused \\
\hline 11909 & Sus & $\begin{array}{l}179 \\
\mathrm{~A}\end{array}$ & $\begin{array}{l}- \\
20 . \\
4\end{array}$ & 29.7 & 6.2 & $\begin{array}{l}10 . \\
9\end{array}$ & 3.2 & $\begin{array}{l}\text { Max. w/ } \\
\text { Teeth }\end{array}$ & $\begin{array}{l}\mathrm{dP} 4 \& \mathrm{M} 1 \\
\text { in wear }\end{array}$ \\
\hline 11800 & Sus & $\begin{array}{l}385 \\
B\end{array}$ & $\begin{array}{l}- \\
19 . \\
1\end{array}$ & 31.7 & 6.5 & $\begin{array}{l}11 . \\
7\end{array}$ & 3.2 & $\begin{array}{l}\text { Max. w/ } \\
\text { Teeth }\end{array}$ & M2 in wear \\
\hline 12906 & Sus & $\begin{array}{l}117 \\
\mathrm{~A}\end{array}$ & $\begin{array}{l}- \\
19 . \\
4\end{array}$ & 32.8 & 6.3 & $\begin{array}{l}12 . \\
6\end{array}$ & 3.0 & Frontal & \\
\hline $\begin{array}{l}\text { ASIL771 } \\
9\end{array}$ & Sus & 43 & $\begin{array}{l}- \\
19 . \\
6\end{array}$ & 33.6 & 6.9 & $\begin{array}{l}12 . \\
8\end{array}$ & 3.1 & $\begin{array}{l}\text { Mand. w/ } \\
\text { Teeth }\end{array}$ & $\begin{array}{l}\text { Age Class 7; } \\
30-52 \\
\text { months }\end{array}$ \\
\hline 10273 & Sus & $\begin{array}{l}325 \\
\text { B }\end{array}$ & 19. & 34.0 & 8.1 & $\begin{array}{l}13 . \\
0\end{array}$ & 3.0 & $\begin{array}{l}\text { Mand. w/ } \\
\text { Teeth }\end{array}$ & $\begin{array}{l}\text { Age Class 1; } \\
<1 \text { month }\end{array}$ \\
\hline 14215 & Sus & $\begin{array}{l}359 \\
\mathrm{~B}\end{array}$ & $\begin{array}{l}- \\
18 . \\
3\end{array}$ & 35.1 & 8.5 & $\begin{array}{l}13 . \\
3\end{array}$ & 3.1 & $\begin{array}{l}\text { Max. w/ } \\
\text { Teeth }\end{array}$ & $\begin{array}{l}\mathrm{dP} 4 \& \mathrm{M} 1 \\
\text { in wear }\end{array}$ \\
\hline 12705 & Sus & $\begin{array}{l}554 \\
\mathrm{C}\end{array}$ & $\begin{array}{l}- \\
21 . \\
2\end{array}$ & 35.1 & 10.6 & $\begin{array}{l}13 . \\
2\end{array}$ & 3.1 & $\begin{array}{l}\text { Max. w/ } \\
\text { Teeth }\end{array}$ & $\begin{array}{l}\text { Age Class 3; } \\
6-8 \text { months }\end{array}$ \\
\hline 13886 & Sus & $\begin{array}{l}332 \\
\mathrm{~B} \\
\end{array}$ & $\begin{array}{l}18 . \\
9\end{array}$ & 36.6 & 7.4 & $\begin{array}{l}13 . \\
9\end{array}$ & 3.1 & Maxilla & M3 in wear \\
\hline 14033 & Sus & $\begin{array}{l}364 \\
B\end{array}$ & $\begin{array}{l}- \\
19 . \\
9\end{array}$ & 36.8 & 6.6 & $\begin{array}{l}13 . \\
9\end{array}$ & 3.1 & Px Ulna & \\
\hline 14353 & Sus & $\begin{array}{l}352 \\
\mathrm{~B}\end{array}$ & $\begin{array}{l}- \\
19 . \\
4\end{array}$ & 37.5 & 5.9 & $\begin{array}{l}14 . \\
3\end{array}$ & 3.1 & $\begin{array}{l}\text { Mand. w/ } \\
\text { Teeth }\end{array}$ & $\begin{array}{l}\text { Age Class 5; } \\
12-16 \\
\text { months }\end{array}$ \\
\hline
\end{tabular}




\begin{tabular}{|c|c|c|c|c|c|c|c|c|c|}
\hline 14668 & Sus & $\begin{array}{l}351 \\
\mathrm{~B}\end{array}$ & $\begin{array}{l}19 . \\
0\end{array}$ & 37.7 & 7.4 & $\begin{array}{l}14 . \\
3\end{array}$ & 3.1 & $\begin{array}{l}\text { Mand. w/ } \\
\text { Teeth }\end{array}$ & \begin{tabular}{|l|} 
Age Class 2- \\
$3 ; 3-8$ \\
months \\
\end{tabular} \\
\hline 14534 & Sus & $\begin{array}{l}554 \\
\mathrm{C}\end{array}$ & $\begin{array}{l}20 . \\
4\end{array}$ & 37.8 & 6.4 & $\begin{array}{l}14 . \\
7\end{array}$ & 3.0 & MC4 Shaft & \\
\hline 11145 & Sus & $\begin{array}{l}310 \\
\mathrm{~B}\end{array}$ & $\begin{array}{l}18 . \\
9\end{array}$ & 38.1 & 6.3 & $\begin{array}{l}14 . \\
7\end{array}$ & 3.0 & $\mathrm{Ph} 2$ & Unfused \\
\hline 14400 & Sus & $\begin{array}{l}375 \\
\text { B }\end{array}$ & $\begin{array}{l}19 . \\
2\end{array}$ & 38.2 & 7.0 & $\begin{array}{l}14 . \\
5\end{array}$ & 3.1 & $\begin{array}{l}\text { Mand. w/ } \\
\text { Teeth }\end{array}$ & $\begin{array}{l}\text { Age Class 5- } \\
7 ; 12-30 \\
\text { months }\end{array}$ \\
\hline 13189 & Sus & $\begin{array}{l}110 \\
\mathrm{~A}\end{array}$ & $\begin{array}{l}19 . \\
1\end{array}$ & 38.5 & 7.1 & $\begin{array}{l}14 . \\
2\end{array}$ & 3.2 & Px. Radius & Fused \\
\hline 12672 & Sus & $\begin{array}{l}575 \\
\mathrm{C}\end{array}$ & $\begin{array}{l}18 . \\
6\end{array}$ & 38.5 & 6.9 & $\begin{array}{l}14 . \\
7\end{array}$ & 3.1 & Ds. Scap. & Fused \\
\hline 13202 & Sus & $\begin{array}{l}100 \\
\mathrm{~A}\end{array}$ & $\begin{array}{l}19 . \\
6\end{array}$ & 38.6 & 6.5 & $\begin{array}{l}14 . \\
8\end{array}$ & 3.1 & MC4 Shaft & Unfused \\
\hline 14137 & Sus & $\begin{array}{l}362 \\
B\end{array}$ & $\begin{array}{l}20 . \\
1\end{array}$ & 38.8 & 5.2 & $\begin{array}{l}14 . \\
7\end{array}$ & 3.1 & Px Ulna & Unfused \\
\hline 13007 & Sus & $\begin{array}{l}113 \\
\mathrm{~A}\end{array}$ & $\begin{array}{l}20 . \\
7\end{array}$ & 38.9 & 7.3 & $\begin{array}{l}15 . \\
1\end{array}$ & 3.0 & $\begin{array}{l}\text { Mand. w/ } \\
\text { Teeth }\end{array}$ & $\begin{array}{l}\text { Age Class 3; } \\
\text { 6-8 months }\end{array}$ \\
\hline 10438 & Sus & $\begin{array}{l}314 \\
B\end{array}$ & $\begin{array}{l}19 . \\
1\end{array}$ & 38.9 & 7.8 & $\begin{array}{l}14 . \\
7\end{array}$ & 3.1 & Ds. Humerus & Fused \\
\hline 12671 & Sus & \begin{tabular}{|l}
575 \\
$\mathrm{C}$ \\
\end{tabular} & $\begin{array}{l}19 . \\
7\end{array}$ & 39.1 & 6.9 & $\begin{array}{l}15 . \\
0\end{array}$ & 3.1 & Ds. Scap. & Fused \\
\hline 14708 & Sus & $\begin{array}{l}356 \\
\mathrm{~B}\end{array}$ & $\begin{array}{l}19 . \\
4\end{array}$ & 39.1 & 8.3 & $\begin{array}{l}15 . \\
3\end{array}$ & 3.0 & Ds. Radius & Unfused \\
\hline 13194 & Sus & $\begin{array}{l}100 \\
\mathrm{~A}\end{array}$ & $\begin{array}{l}18 . \\
8\end{array}$ & 39.2 & 6.4 & $\begin{array}{l}15 . \\
0\end{array}$ & 3.1 & Ds. Humerus & Fused \\
\hline 10115 & Sus & $\begin{array}{l}322 \\
\mathrm{~B}\end{array}$ & $\begin{array}{l}19 . \\
2\end{array}$ & 39.3 & 7.1 & $\begin{array}{l}15 . \\
0\end{array}$ & 3.1 & $\begin{array}{l}\text { Max. w/ } \\
\text { Teeth }\end{array}$ & $\begin{array}{l}\text { dP4 \& M1 } \\
\text { in wear }\end{array}$ \\
\hline 12365 & Sus & $\begin{array}{l}168 \\
\mathrm{~A}\end{array}$ & $\begin{array}{l}19 . \\
3\end{array}$ & 39.3 & 6.5 & $\begin{array}{l}15 . \\
3\end{array}$ & 3.0 & $\begin{array}{l}\text { Max. w/ } \\
\text { Teeth }\end{array}$ & $\begin{array}{l}\mathrm{dP} 3 \& \mathrm{dP} 4 \\
\text { in wear }\end{array}$ \\
\hline 14096 & Sus & 364 & & 39.5 & 6.9 & 15. & 3.0 & \begin{tabular}{|l} 
Ds. Radius \\
\end{tabular} & Unfused \\
\hline
\end{tabular}




\begin{tabular}{|c|c|c|c|c|c|c|c|c|c|}
\hline & & B & \begin{tabular}{|l}
19. \\
0.
\end{tabular} & & & 3 & & & \\
\hline 12603 & Sus & $\begin{array}{l}556 \\
\mathrm{C}\end{array}$ & $\begin{array}{l}19 . \\
1\end{array}$ & 39.5 & 6.9 & $\begin{array}{l}14 . \\
9\end{array}$ & 3.1 & Ds. Radius & Unfused \\
\hline 12066 & Sus & $\begin{array}{l}176 \\
\mathrm{~A}\end{array}$ & $\begin{array}{l}18 . \\
9\end{array}$ & 39.6 & 6.7 & $\begin{array}{l}15 . \\
2\end{array}$ & 3.1 & $\begin{array}{l}\text { Mand. w/ } \\
\text { Teeth }\end{array}$ & $\begin{array}{l}\text { Age Class 3; } \\
\text { 6-8 months }\end{array}$ \\
\hline 12545 & Sus & $\begin{array}{l}557 \\
\mathrm{C}\end{array}$ & $\begin{array}{l}20 . \\
1\end{array}$ & 39.3 & 5.7 & $\begin{array}{l}14 . \\
6 \\
\end{array}$ & 3.2 & Ds Scap & Unfused \\
\hline 13435 & Bos & $\begin{array}{l}110 \\
\mathrm{~A}\end{array}$ & $\begin{array}{l}25 . \\
0\end{array}$ & 12.0 & 5.4 & 3.1 & 4.6 & Ilium Shaft & Unfused \\
\hline 110426 & Bos & $\begin{array}{l}312 \\
\mathrm{~B} \\
\end{array}$ & $\begin{array}{l}20 . \\
4\end{array}$ & 24.4 & 6.6 & 8.8 & 3.2 & Calcaneus & Fused \\
\hline 12096 & Bos & $\begin{array}{l}375 \\
\text { B }\end{array}$ & $\begin{array}{l}19 . \\
1\end{array}$ & 28.5 & 6.0 & $\begin{array}{l}11 . \\
0\end{array}$ & 3.0 & Ds. Humerus & Fusing \\
\hline 12933 & Bos & $\begin{array}{l}121 \\
\mathrm{~A}\end{array}$ & $\begin{array}{l}-25 . \\
0\end{array}$ & 31.4 & 5.1 & 6.6 & 5.5 & $\begin{array}{l}\text { Mand. w/ } \\
\text { Teeth }\end{array}$ & $\begin{array}{l}\text { Wear Stage } \\
26-27 ; 2-3 \\
\text { years }\end{array}$ \\
\hline 12749 & Bos & $\begin{array}{l}121 \\
\mathrm{~A}\end{array}$ & $\begin{array}{l}24 . \\
1\end{array}$ & 31.9 & 5.9 & 8.2 & 4.5 & MC34 Shaft & \\
\hline 14394 & $\begin{array}{l}\text { Gaze } \\
\text { lla }\end{array}$ & $\begin{array}{l}352 \\
\mathrm{~B}\end{array}$ & $\begin{array}{l}22 . \\
8\end{array}$ & 37.8 & 5.6 & $\begin{array}{l}11 . \\
4\end{array}$ & 3.9 & Ds. Tibia & Fused \\
\hline $\begin{array}{l}\text { ASIL780 } \\
8\end{array}$ & Sus & 927 & $\begin{array}{l}19 . \\
9\end{array}$ & 15.4 & 7.0 & 5.8 & 3.1 & $\begin{array}{l}\text { Max. w/ } \\
\text { Teeth }\end{array}$ & $\begin{array}{l}\text { dP4 \& M1 } \\
\text { in wear, M2 } \\
\text { erupting }\end{array}$ \\
\hline $\begin{array}{l}\text { ASIL774 } \\
0 \\
\end{array}$ & Sus & 9 & $\begin{array}{l}19 . \\
8\end{array}$ & 20.2 & 7.0 & 7.4 & 3.2 & $\begin{array}{l}\text { Mand. w/ } \\
\text { Teeth }\end{array}$ & $\begin{array}{l}\text { Age Class 3- } \\
4 ; 6-12 \\
\text { months } \\
\end{array}$ \\
\hline $\begin{array}{l}\text { ASIL773 } \\
5 \\
\end{array}$ & Sus & $\begin{array}{l}161 \\
\text { A }\end{array}$ & $\begin{array}{l}19 . \\
7\end{array}$ & 22.3 & 6.9 & 8.5 & 3.1 & $\begin{array}{l}\text { Max. w/ } \\
\text { Teeth }\end{array}$ & M2 in wear \\
\hline $\begin{array}{l}\text { ASIL772 } \\
0 \\
\end{array}$ & Sus & 19 & $\begin{array}{l}21 . \\
0\end{array}$ & 27.5 & 6.7 & $\begin{array}{l}10 . \\
3\end{array}$ & 3.1 & $\begin{array}{l}\text { Mand. w/ } \\
\text { Teeth }\end{array}$ & $\begin{array}{l}\text { Age Class 3; } \\
\text { 6-8 months }\end{array}$ \\
\hline 13037 & Sus & $\begin{array}{l}110 \\
\mathrm{~A}\end{array}$ & $\begin{array}{l}25 . \\
9\end{array}$ & 28.8 & 5.4 & 9.1 & 3.7 & $\begin{array}{l}\text { Mand. w/ } \\
\text { Teeth }\end{array}$ & $\begin{array}{l}\text { Age Class 3; } \\
\text { 6-8 months }\end{array}$ \\
\hline
\end{tabular}




\section{AUTHOR ACCEPTED MANUSCRIPT}

** When applicable, age classes used for Sus mandibles following Lemoine et al.'s (2014) "specific system"; Grant (1982) used for Bos. 


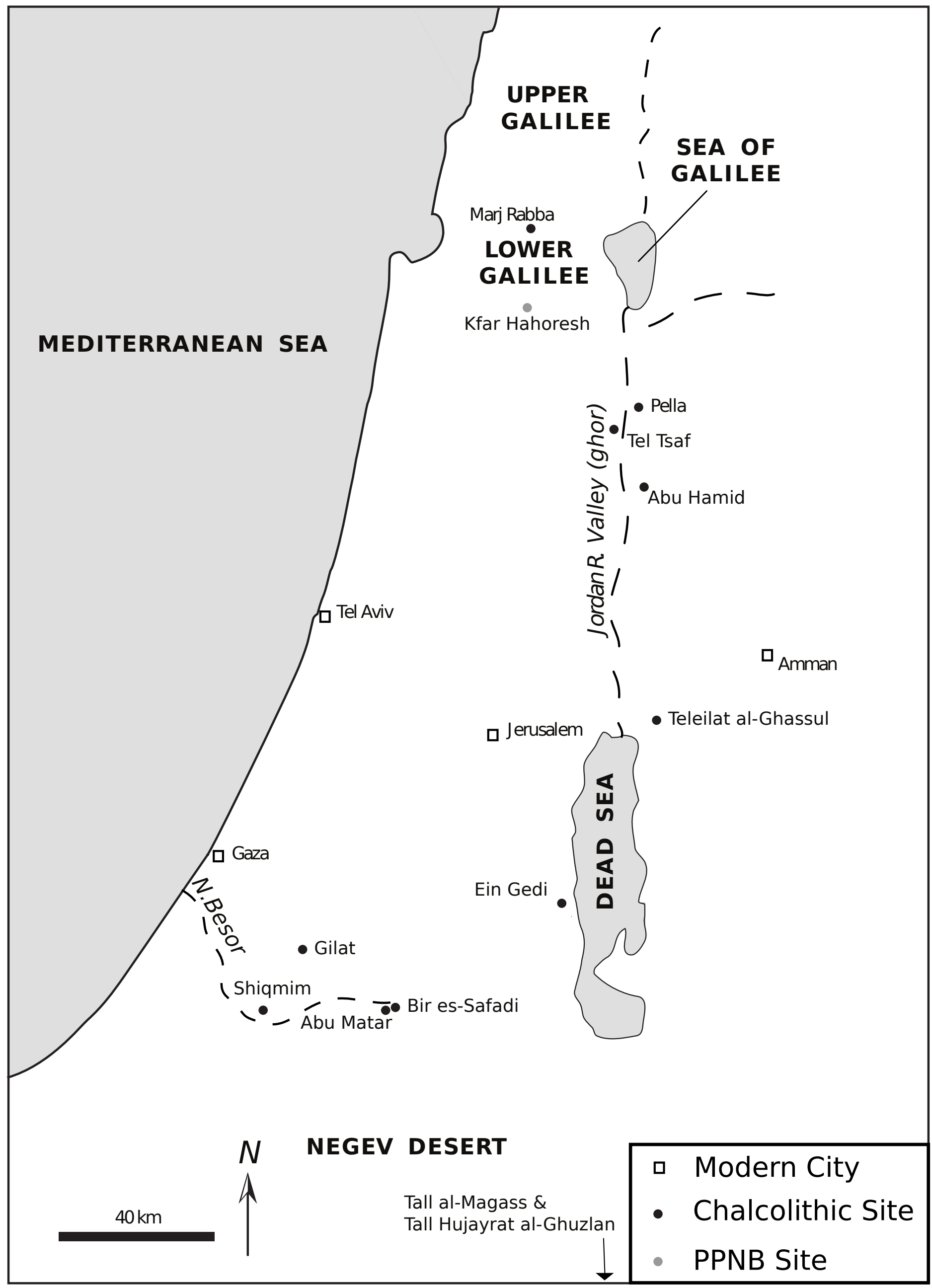




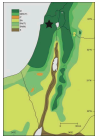




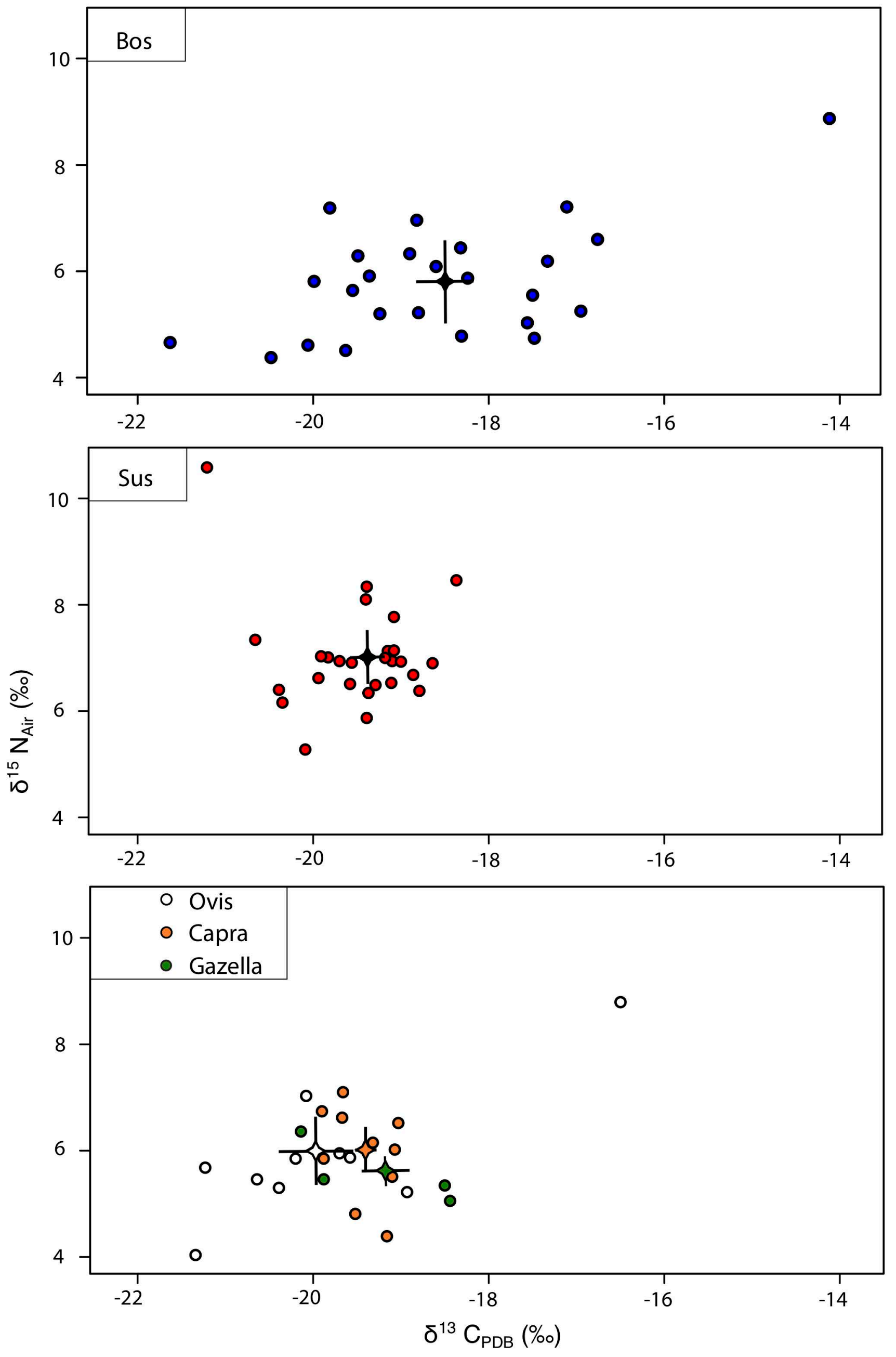




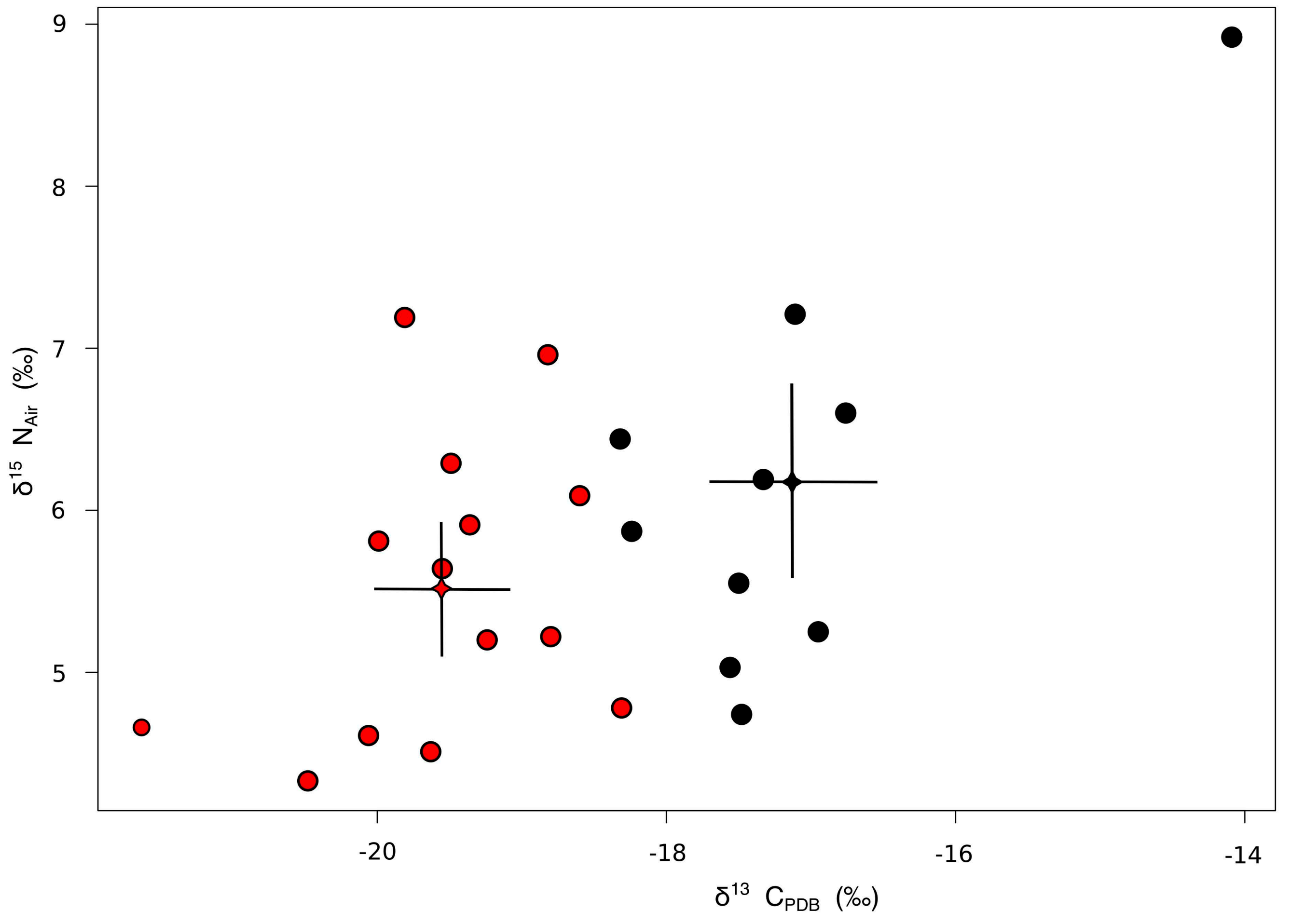

